William \& Mary Law School

William \& Mary Law School Scholarship Repository

Faculty Publications

Faculty and Deans

Summer 2020

\title{
Toolkit or Tinderbox? When Legal Systems Interface Conflict
}

Christie S. Warren

Follow this and additional works at: https://scholarship.law.wm.edu/facpubs

Part of the Comparative and Foreign Law Commons, International Law Commons, and the Rule of Law Commons

Copyright c 2020 by the authors. This article is brought to you by the William \& Mary Law School Scholarship Repository.

https://scholarship.law.wm.edu/facpubs 


\title{
Toolkit or Tinderbox? When Legal Systems Interface Conflict
}

\author{
Christie S. Warren $\dagger$
}

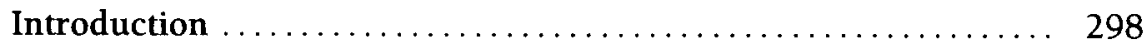

I. Conflict and Legal Systems .................. 301

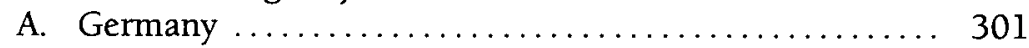

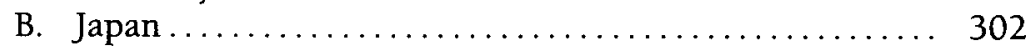

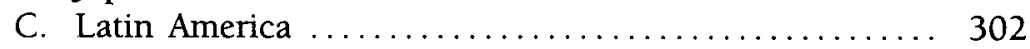

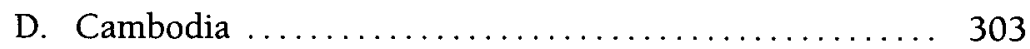

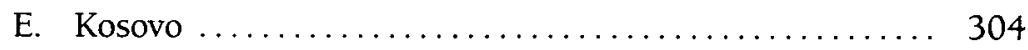

F. Timor-Leste ............................. 305

II. Legal System Reform: A Fraught Enterprise Under the Best of Circumstances....................... 306

III. The Role of International Advisers and the Question of

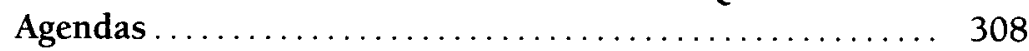

IV. Applicable Legal Frameworks ................ 311

A. Frameworks During Occupation ............... 311

B. Frameworks During Peacekeeping Operations ........ 312

V. Which Legal System? A Comparative Approach ......... 314

VI. Toward a Comparative Problem-Solving Model During Post-Conflict Reconstruction Processes ............. 317

A. Conflict Mapping $\ldots \ldots \ldots \ldots \ldots \ldots \ldots \ldots \ldots \ldots \ldots \ldots \ldots$

B. The Comparative Law Methodology ............ 319

C. Triers of Fact ............................. 320

D. Control of Investigations in Criminal Cases ......... 321

E. Role of Police ............................ 321

$\dagger$ Professor of the Practice of International and Comparative Law; founding Director of the Center for Comparative Legal Studies and Post-Conflict Peacebuilding, William \& Mary Law School. This Article is the culmination of research undertaken during my tenure as Fulbright-Schuman Distinguished Chair at the European University Institute (Florence, Italy) during the 2016-2017 academic year and as Visiting Professor of Constitutional Law at the Universidad Autónoma de Madrid (Madrid, Spain) during the spring semester of 2019. I am grateful to those institutions for supporting my work and providing access to their resources. For their comments and advice in connection with this Article, 1 thank Koen Lenaerts, Martti Ahtisaari, Gábor Halmai, Miguel Maduro, Mohammad Fadel, Marian Ahumada, Jose M. de Areilza, Roger K. Warren, Linda Malone, Rudolf "Schnutz" Durr, Peter Wallensteen, Stephen Thaman, Louis Aucoin, Christopher Lehmann, Catherine Newcombe, S.P. Harish, Vivienne O'Connor, and Colette Rausch. For their feedback during workshops at which my initial research was presented, I thank participants at the Fifth Annual Contemporary Fiqhî Issues Workshop at the Al-Mahdi Institute and students at the Center for Constitutional Democracy at the University of Indiana Maurer School of Law. For their invaluable research assistance, I thank Jennifer Sekula, Jessica Krauss, Rebecca Wescott, Katharine Warren, and Kelsey Knitter. I am deeply grateful to the Fulbright-Schuman Program for making this research possible.

53 CORNELl INT'L L.J. 297 (2020) 
F. Role of Defense Lawyers ................. 321

G. Secrecy of the Investigation Phase .............. 322

H. Judicial Control of Expert Witnesses............ 322

I. Guilty Pleas and Plea Bargains............... 323

J. Admissibility of Evidence .................. 324

K. Joint Civil and Criminal Trials ................ 325

L. Judicial Oversight of Civil Cases ............... 325

M. Community-Based Institutions .............. 326

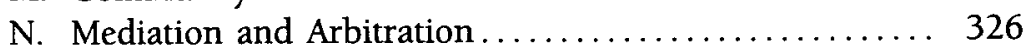

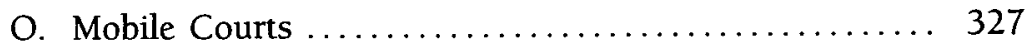

VII. Skepticism Towards Hybridity .................. 327

VIII. Hybridity in Legal Systems .................. 329

IX. Hybridity in International and Domestic Courts and the

Model Codes Project ...................... 330

X. The Need for Systemic Thinking ............... 334

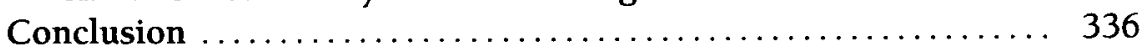

\section{Introduction}

The collapse of justice might manifest metaphorically. For example, in November 1985, a guerrilla group frustrated by the government's violation of a ceasefire stormed Colombia's Palace of Justice and held all twentyfive of the nation's Supreme Court justices-along with hundreds of civilians-hostage. ${ }^{1}$ In March 2017, more than thirty years later, judges and lawyers working in the Palace of Justice in Damascus were targeted in a double bombing that resulted in dozens of deaths. ${ }^{2}$ In July 2018, protesters held demonstrations in front of Port-au-Prince's Palais de Justice demanding the release of Haitians arrested during a revolt against fuel increases that disproportionately impacted the poor. ${ }^{3}$

In the aftermath of conflict, the need to stabilize the Rule of Law

1. Christopher Woody, 33 Years Ago, Rebels Allegedly Backed by Pablo Escobar Stormed Colombia's Palace of Justice-Here's How the Terrifying Siege Went Down, Bus. INSIDER (Nov. 8, 2018, 9:11 AM), https://www.businessinsider.com/colombia-palace-ofjustice-siege-2016-11 [https://perma.cc/XDP4-8CBS]; see Luz Estella Nagle, The Cinderella of Government: Judicial Reform in Latin America, 30 CAL. W. INT'L L.J. 345, 356 (2000) ("Such was the case in Col[o]mbia in 1985 during the presidency of Belisario Betancur, when the military staged what essentially amounted to a coup d'etat against that nation's Supreme Court. This notorious incident was sparked by the poorly orchestrated takeover of the Palace of Justice by the leftist guerrilla group, M-19."); Id. at 356 n.74 ("M-19's ill-planned operation was intended to call national attention to the movement's social and political platform after negotiations with the Betancur administration had broken down. The palace was destroyed during the military's assault and nearly all the justices were killed.").

2. ILAC Rule of Law Assessment Report: Syria 2017, InT'L Legal Assistance ConsorTIUM 1, 7 (2017), http://www.ilacnet.org/wp-content/uploads/2017/04/Syria2017.pdf [https://perma.cc/3SS]-CSFD] [hereinafter ILAC Report].

3. France Francois, Unrest in Haiti: What You Need to Know, Nat'l Pub. Radio: LATiNo USA (July 24, 2018), https://www.latinousa.org/2018/07/24/unrest-in-haitiwhat-you-need-to-know [https://perma.cc/34TP-KQS7]. 
almost always engenders broad consensus, ${ }^{4}$ but rebuilding a courthouse is a far easier task than rebuilding a justice system. Whether international bodies, such as the United Nations (U.N.); regional bodies, such as the European Union (EU) or the North Atlantic Treaty Organization (NATO); or individual state actors take the lead in reconstruction efforts, establishing a legitimate legal framework and strengthening institutions capable of delivering just results is considered a primary step in rebuilding societies that were destabilized or destroyed by conflict.

However, as Rachel Kleinfeld observed, fourteen years after Thomas Carothers' pathbreaking analysis of the Rule of Law revival, little had changed, and the Rule of Law remained as elusive as ever. ${ }^{5}$ Kleinfeld argued that Rule of Law "practitioners and scholars keep waking up to the same predicaments, noting them in the same working papers, and then going back to do the same things." 6 New models are clearly needed. ${ }^{7}$

The U.N. has recognized the need to reevaluate its post-conflict legal reform strategy. In 2000, the United Nations Secretary General Kofi A. Annan convened a "high-level Panel to undertake a thorough review of the United Nations peace and security activities, and to present a clear set of specific, concrete and practical recommendations to assist the United Nations in conducting such activities better in the future." 8 The Panel, chaired by former Foreign Minister of Algeria Lakhdar Brahimi, issued its report later that year: the Brahimi Report. ${ }^{9}$ Reflecting on the experience gained throughout U.N. peacekeeping missions during the past decades in Cambodia, El Salvador, Angola, and Mozambique, the Brahimi Report recommended a doctrinal shift in peacekeeping operations. The shift reflected an increased focus on strengthening Rule of Law institutions and respecting human rights in post-conflict environments. ${ }^{10}$

4. Thomas Carothers, Foreword to Rachel Kleinfeld, Advancing the Rule of Law Abroad: Next Generation Reform, at ix (2012).

5. Rachel Kleinfeld, Advancing the Rule of Law abroad: Next Generation REFORM 2 (2012).

6. Id.

7. The unaddressed costs and consequences of conflict are well established. Conflict tends to recur in countries that have experienced prior conflict without successfully addressing root causes. WORLd BANK, World DeVElopment REPORT 2011: CONFLiCt, SECURITY, AND DEVELOPMENT 2 (2011); see also Joint Staff Working Document on Advancing the Principle of Complementarity: Toolkit for Bridging the Gap Between International and National Justice, at 11, SWD (2013) 26 final (Feb. 22, 2013) [hereinafter Joint Staff Working Document].

[M]ore than $90[\%]$ of civil wars in the 2000 s occurred in countries that already experienced a civil war in the previous [thirty] years. . . "A country making development advances ... loses an estimated 0.7[\%] of GDP every year for each neighbour in conflict. The average cost of civil war is equivalent to more than [thirty] years of GDP growth for a medium-size developing country. . . In other words, a major episode of violence, unlike natural disasters or economic cycles, can wipe out an entire generation of economic progress."

Id. at 5 (citing to WORLD BANK, supra note 7, at 5-6).

8. U.N. Secretary-General, Report of the Panel on United Nations Peace Operations, at i, U.N. Doc. A/55/305-S/2000/809 (Aug. 21, 2000) [hereinafter Brahimi Report].

9. Id.

10. Id. at 22 . 
The U.N. was not alone in articulating the need to address legal system reform head-on following conflict. In 2005, the Office of the Coordinator for Reconstruction and Stabilization, located within the United States Department of State, ${ }^{11}$ issued the Post-Conflict Reconstruction Essentials Tasks Matrix (Tasks Matrix). The Tasks Matrix provides a toolkit for planners supporting countries that are transitioning from armed conflict or civil strife to sustained stability. ${ }^{12}$ The section titled Legal System Reform recommends legal system reorganization, code and statutory reform, increased citizen participation, and institutional reform. Initial recommended responses include developing strategies to rebuild criminal justice systems and identifying countries that can serve as models and sources of expertise. ${ }^{13}$ In 2006, the African Union issued its own Policy on Post-Conflict Reconstruction and Development (the Policy). ${ }^{14}$ Recognizing that postconflict environments are often characterized by institutional breakdown and the collapse of law and normative frameworks, the Policy seeks to address the root causes of conflict effectively and emphasizes the exigency of reestablishing the Rule of Law. ${ }^{15}$

During the same period, similar recommendations were made by scholars and practitioners engaged in post-conflict reconstruction. Jane Stromseth, examining reconstruction efforts following military interventions, argued that building a legitimate legal system should be a vital aspect of post-conflict reconstruction efforts and stressed that it must be addressed expeditiously. ${ }^{16}$ In the same vein, Kleinfeld proposed a shift away from institution-based definitions of Rule of Law reform, which compare legal institutions to Western counterparts, toward an ends-based para-

11. Secretary of State Colin Powell created the Office of the Coordinator for Reconstruction and Stabilization (S/CRS) on August 5, 2004 to enhance the U.S.' institutional capacity to respond to crises involving failing, failed, and post-conflict states as well as complex emergencies. The core mission of S/CRS was to lead, coordinate, and institutionalize the U.S. Government's civilian capacity to prevent or prepare for post-conflict situations. The S/CRS was also meant to help stabilize and reconstruct societies in transition from conflict or civil strife so they could reach a sustainable path toward peace, democracy, and a market economy. About S/CRS, U.S. DEP'T STATE, https://20012009.state.gov/s/crs/cl2936.htm [https://perma.cc/UUP2-MSJD] (last visited Aug. 12, 2019). On November 22, 2011, the U.S. Department of State replaced S/CRS with the Bureau of Conflict and Stabilization Operations. The mandate of the Bureau focuses on political instability, countering violent extremism, and security sector stabilization, which includes informing policies on detention, prosecution, or rehabilitation. Bureau of Conflict and Stabilization Operations, U.S. DEP'T STATE, https://www.state.gov/ bureaus-offices/under-secretary-for-civilian-security-democracy-and-human-rights/ bureau-of-conflict-and-stabilization-operations [https://perma.cc/B2AH-UA98] (last visited Aug. 12, 2019).

12. Office of the Coordinator for Reconstruction and Stabilization, Post-Conflict Reconstruction Essentials Tasks Matrix, U.S. Dep't StaTe (Apr. 1, 2005), https://200I2009.state.gov/s/crs/rls/52959.htm [https://perma.cc/DH4J-3VS9].

13. Id.

14. See generally African Union, Policy on Post-Conflict Reconstruction and DeVElopMent (2006).

15. Id. T 5.

16. Janf Stromseth et al., Can Might Make Rights? Butlding the Rule of Law After Military Interventions 178, 192 (Cambridge Univ. Press 2006). 
digm that permits reformers to focus on the delivery of effective justice. ${ }^{17}$

This Article begins by analyzing the nexus and intersection between legal systems and conflict in several historical contexts. It then examines issues raised during legal system reform that are exacerbated by their proximity to conflict and discusses the role of international actors and their agendas-both overt and covert-in Rule of Law work. Finally, this Article proposes a problem-solving model that utilizes a Comparative Law approach for post-conflict reconstruction. This model is not limited by traditional boundaries of legal system theory but instead seeks to address specific legal deficits that contribute to conflict and considers component aspects of various legal systems as a solution to conflict.

\section{Conflict and Legal Systems}

Intersections between laws, legal systems, and conflicts are not new, and they are not likely to disappear. ${ }^{18}$ A brief survey of several past, postconflict reconstruction processes conveys this observation.

\section{A. Germany}

Legal system reform has intersected with conflict since at least 1948, when Germany's entire legal system was restructured by advisers from the Allied Powers who determined that legislation infused with National Socialist principles had contributed to World War II. At the war's conclusion, these advisers set out to purge the legal system of Hitler's policies, which synchronized justice with Nazi ideologies. ${ }^{19}$ The task, however, turned out to be more complicated than advisers initially realized. Because the Nazi regime followed German positivist tradition, a large amount of legislation had been enacted to ensure that judges would have positive law to follow. ${ }^{20}$ Denazification required that every aspect of the German legal system-including seemingly neutral areas such as corporate, family, insurance, patent, agricultural, and public health law-be examined not only for language, but also for impact: "a task of truly Justinian proportions." 21 The process was made more difficult by the diverse legal backgrounds of the advisers, who spoke and wrote in different languages. ${ }^{22}$

17. KleINFELD, supra note 5 , at 12-17.

18. In Syria, for example, legal reform has already been identified as a critical aspect of future reconstruction efforts since the system's intimacy with the current government has resulted in a loss of legitimacy. See ILAC Report, supra note 2, at 9.

19. Andrew Szenajda, Restoring Administrations of Justice in Early Practice: AmericanOccupied Germany 1945-1949, AMSTERdam L.F., Winter 2014, at 35, 39.

20. Karl Loewenstein, Law and the Legislative Process in Occupied Germany: 1, 57 YALE L.J. 724, 734-35 (1948).

21. Id. at 734. The enormity of challenges involved in post-conflict reconstruction appears to attract historical superlatives. Hansjoerg Strohmeyer describes the challenges facing legal advisers in Timor-Leste immediately following the 1999 conflict as "truly Promethean." Hansjoerg Strohmeyer, Building a New Judiciary for East Timor: Challenges of a Fledgling Nation, 11 CRIM. L.F. 259, 262 (2000).

22. Loewenstein, supra note 20 , at $743-44$. 


\section{B. Japan}

In post-World War II Japan, system change was just as deliberate and thorough as it was in Germany. Under the orders of the Supreme Commander for the Allied Powers, a bold, neocolonial plan to entirely reconfigure Japanese law was conceived and undertaken despite the acknowledged realization that enduring political and social revolutions should emanate from within indigenous societies. ${ }^{23}$ In addition to abolishing the government-sponsored cult of Shinto, liberalizing the constitution, extending franchise to women, promoting labor unionization, and democratizing the economy, all civil and criminal laws were reformed over the course of two years as part of an overt effort to eliminate all vestiges of previous Japanese society. ${ }^{24}$ These legal reforms did not sit well with powerful Japanese elites who would have preferred to ignore root causes of militarism, repression, and aggression by simply depicting the war as an aberration. ${ }^{25}$

\section{Latin America}

The relationship between legal systems and conflict in Latin America is stark. Civil code systems were introduced throughout Latin America during periods of colonization. ${ }^{26}$ One scholar goes so far as to state that Latin America's colonial past has left it more burdened than many other developing regions of the globe because of "autocratic caprices of Iberian monarchies [who] pillaged a fertile and abundant land for the sake of religious zealousness and strategic hegemony over other Old World rivals." 27 More than five hundred years later, colonial and post-colonial governments and economies in Latin America, founded on mercantile systems with no interest in representative democracy, still favored elitist governmental structures in which the elite accumulated wealth and entrenched themselves in positions of power and influence. ${ }^{28}$ Ultimately, conflict, violence, and uprisings erupted in many of these Latin American countries.

In the late 1980s and 1990s, reform of Latin American legal systems was of great interest to human rights activists, policy makers, and international funders because corruption of the judiciary, police, and other institutions caused loss of faith in justice systems. In Guatemala and Colombia, abuses of the secret investigation phase-a hallmark of civil code systemswere linked to astronomical rates of impunity, rampant corruption, brib-

23. John W. Dower, Embracing Japan in the Wake of World War II Defeat 80 (1999).

24. Id. at 82 .

25. Dower states: "On their own, these civilian elites might have conducted a mild post-war purge of military leaders and perhaps instituted some small political reforms aimed at preventing military excesses in the future." Id. at 84 .

26. See generally Nagle, supra note 1.

27. Id. at 348 .

28. Id. 
ery, and violence. ${ }^{29}$ In 1994, reforms of the Guatemalan criminal law and procedure codes were part of an effort to recover from thirty-six years of civil war and a legacy of oppressive military rule..$^{30}$ In both countries, inquisitorial processes were abandoned in favor of adversarial features that promised increased transparency and fewer opportunities for corruption. ${ }^{31}$

\section{Cambodia}

Although the legal system of Cambodia has been influenced throughout history by a variety of other systems, including early influences from India ${ }^{32}$ and France, the Khmer Rouge period of 1975-197933 left behind a very specific legal legacy. The Communist Party of Kampuchea (CPK), or Khmer Rouge, abolished all laws and institutions and ruled through a central dictatorship that exercised complete control over every aspect of its citizens' lives. ${ }^{34}$ All but a small handful of people were killed-regardless of their level of education. ${ }^{35}$ Following the signing of the Paris Peace Accords in 1991, a period of reconstruction began that included the participation of international advisers. The 1993 constitution, drafted with international assistance, preserved the validity of previously enacted legislation to the extent that such legislation was not inconsistent with the constitution itself. ${ }^{36}$ Therefore, although there were no positive law remnants of the CPK implicated in the conflict, their complete absence, along with the fact that almost every lawyer had been killed, left a post-conflict legacy that had never existed elsewhere. Post-conflict reconstruction was further

29. Andrés Torres, From Inquisitorial to Accusatory: Colombia and Guatemala's Legal Transition 2-4 (Law \& Justice in the Americas Working Paper Series, Paper No. 4, 2007), https://lawdigitalcommons.bc.edu/ljawps/4 [https://perma.cc/HNQ8-VUCY].

30. Id. at 1.

31. Id. at 6 . Whether these legal system reforms were successful and whether they contributed to successful transitions to peace in Latin America remains an open question. Commentators still characterize the Colombian justice system as chaotic and corrupt. See Hermán Gutiérrez, Colombia: Overview of Corruption and Anti-corruption, TRANSPARENCY INT'L (Mar. 15, 2003), https://www.transparency.org/files/content/corruptionqas/373_Colombia_Overview_of_corruption_and_anti-corruption.pdf [https:// perma.cc/R5SY-CG3K]. Some believe that reforms did not transform state institutions into embracing disaffected groups and reducing rates of impunity; instead, elite groups continue to use justice systems to "reward followers, ensure the outcomes of certain distributive decisions, and otherwise enhance the political advantage of one partisan faction or another." Nagle, supra note 1, at 354 (quoting LinN A. HAMMERGREN, THE Politics of Justice and Justice Reform in Latin America: The Peruntan Case in Comparative Perspective 27 (1998)). In the end, Nagle wonders whether judicial reform efforts are in fact responsible for the lack of socioeconomic development and persistent conflict in Latin America. Id. at 346.

32. Jörg Menzel, Cambodian Law: Some Comparative and International Perspectives, in Introduction to Cambodian law 479, 485 (Hor Peng et al. eds., 2012).

33. Jennifer Holligan \& Tarik Abdulhak, Overview of the Cambodian History, Governance and Legal Sources, GlobaLex (Apr. 2011), https://www.nyulawglobal.org/globalex/ Cambodia.html\#postdkperiod [https://perma.cc/WD5E-MPSR].

34. Id.

35. See Menzel, supra note 32, at 1; Janet Vo, Note, Breaking the Cycle: Shifting Towards Effective Education Reform to Overcome Poverty and Abate Cambodia's Sex Industry, 39 SuFfolk Transnat'l L. Rev. 455, 455 (2016).

36. Holligan \& Abdulhak, supra note 33. 
complicated by the fact that Cambodians were deeply reluctant to use statesponsored legal forums due to their "dislike for adversarial dispute resolution, distrust of the state, and a strong cultural tradition of turning to monks and those higher in the social hierarchy for resolution of disputes." 37 Since law had not protected them from the tyranny of the Khmer Rouge, the general public felt little but contempt for the Rule of Law and legal system. ${ }^{38}$

\section{E. Kosovo}

In Kosovo, longstanding ethnic discrimination and tension functioned as a primary impetus for violence. ${ }^{39}$ In 1999 , ethnic cleansing by Serbs against Kosovar Albanians and airstrikes by NATO were followed by Security Council Resolution 1244 establishing a United Nations Transitional Administration in Kosovo (UNMIK). ${ }^{40}$ Since ethnic Albanians had not participated in the justice system during the period of Serbian control, ${ }^{41}$ the subsequent withdrawal of Serbian military and police left virtually no trained justice sector personnel and a significant question as to what law would apply in criminal, land title, and other cases. ${ }^{42}$ The decision of Special Representative of the Secretary General Bernard Kouchner to restore the legal framework that had been in place prior to the NATO intervention was deeply resented by ethnic Albanians, who considered those laws symbolic of Serbian oppression. ${ }^{43}$ Even though none of the laws were facially discriminatory, they had been applied by Slobodan Milošević in a discriminatory manner and were considered to have been among the most powerful tools of repression and discrimination during the years of Serbian control. ${ }^{44}$ Thus, Kouchner's decision received significant backlash, which made it impossible to initiate any sort of legal proceeding. Ultimately, UNMIK was compelled to issue a new regulation declaring that the applicable legal framework would be the one in place prior to the date Serbian control had begun, even though those laws were far less protective of international human rights norms than the so-called "Serb laws." 45

37. Dolores A. Donovan, Cambodia: Building A Legal System from Scratch, 27 INT'L LAw. 445, 454 (1993).

38. See id. at 453.

39. Seth G. Jones et al., Establishing Law and Order After Conflict 28 (2005).

40. Stromseth et Al., supra note 16 , at 37.

41. During this period, Kosovar Albanians turned to traditional alternative dispute resolution mechanisms to resolve disputes. Using village elders, Reconciliation Councils solved approximately one thousand longstanding blood feuds during the $1990 \mathrm{~s}$. See U.S. Agency Int'l Dev. et al., Judicial Assessment Mission II 4 (2001).

42. See Stromseth et al., supra note 16, at 316.

43. Id. at 316-17; see also Hansjörg Strohmeyer, Collapse and Reconstruction of a Judicial System: The United Nations Missions in Kosovo and East Timor, 95 Am. J. INT'L L. 46, 56-59 (2001).

44. Michael E. Hartmann, International Judges and Prosecutors in Kosovo: A New Model for Post-Conflict Peacekeeping 4 (2003); see also Strohmeyer, supra note 43, at 58-59.

45. See Stromseth et al., supra note 16 , at 317. 


\section{F. Timor-Leste}

In 1999, the people of Timor-Leste took advantage of Indonesian President B.J. Habibie's offer to participate in a referendum to determine the future of their country, which had been subject to colonization for more than five hundred years-first by Portugal and later by Indonesia. ${ }^{46}$ On the day of the referendum, $98 \%$ of eligible Timorese voters cast ballots. ${ }^{47}$ When the results of the referendum were announced, $78.5 \%$ of the population had voted for independence, rejecting Indonesia's offer of autonomy. ${ }^{48}$ Immediately following the referendum, Indonesian military forces and prointegration militias launched a campaign of violence, looting, and arson throughout the country. ${ }^{49}$ When the U.N. established the U.N. Transitional Administration in East Timor (UNTAET), it gave UNTAET executive, legislative, and judicial authority. ${ }^{50}$

During its initial assessment, UNTAET found that virtually all trained lawyers had fled Timor during the post-referendum violence. ${ }^{51}$ Since the Timorese had not been permitted to participate in their own government institutions during the centuries of colonization, very few judicial and prosecutorial personnel remained, and none of them had any courtroom experience. ${ }^{52}$

In its first regulation, implemented in accord with its legislative mandate, UNTAET stated that Indonesian laws that had been in effect in East Timor prior to October 25,1999 , would remain in effect to the extent they were not inconsistent with international human rights standards or subsequent UNTAET regulations. ${ }^{53}$ However, as UNTAET's Deputy Principal Legal Adviser found, Indonesian laws were politically charged and unacceptable to the Timorese, almost all of whom had lost family members during the struggle for independence. ${ }^{54}$

46. Louis Aucoin \& Michele Brandt, East Timor's Constitutional Passage to Independence, in Framing the State in Times of Transition: Case Studies in Constitution MakING 245, 246 (Laurel E. Miller \& Louis Aucoin eds., 2010); see also Susan Harris Rimmer $\&$ Juli Effi Tomaras, Aftermath Timor Leste: Reconciling Competing Notions of Justice, PARLIAMENT Austl. (May 22, 2006), https://www.aph.gov.au/About_Parliament/Parliamentary_Departments/Parliamentary_Library/Publications_Archive/archive/TimorLeste [https://perma.cc/Z9X]-76QG].

47. United Nations Transitional Administration in East Timor: Background, UNITED NATIONS (May 2002), https://peacekeeping.un.org/en/mission/past/etimor/etimor.htm [https://perma.cc/E8G5-XRAQ].

48. Id.

49. Id.

50. Aucoin \& Brandt, supra note 46, at 249.

51. See U.N. Secretary-General, Report of the Secretary General on the Situation in East Timor, 9 33, U.N. Doc. S/1999/1024 (Oct. 4, 1999); see also Strohmeyer, supra note 21 , at $262-63$.

52. Strohmeyer, supra note 21, at 269.

53. Id. at 267.

54. See Strohmeyer, supra note 43, at 48. Opposition to former tools of Indonesian control was further enflamed by the final report of the Commission for Reception, Truth and Reconciliation, titled Chegal. The report alleged that the Indonesian military had used napalm and poisoned food supplies to kill members of the resistance movement. It also accused the military of using rape, sexual slavery, and sexual violence to inflict 
Timor's complex legal history, the result of centuries of colonization and periods of intense violence, led to widespread mistrust of formal laws and legal institutions and an ongoing preference for traditional legal practices. ${ }^{55}$ Reluctance on the part of government leaders, including the Prime Minister, to follow formal laws is cited as a cause of ongoing violence in the country. 56

\section{Legal System Reform: A Fraught Enterprise Under the Best of Circumstances}

It is not surprising that in none of the past, post-conflict cases discussed above was legal system reform carried out in a straightforward manner. Law is more than just a body of state-sponsored rules and institutions, and reforming a legal system requires more than merely redrafting legislation. Law reflects a deeply complex collection of cultural commitments and institutional structures valued by those within its jurisdiction..$^{57}$ When undertaken organically and willingly, legal reform can bring about welcomed changes accompanied by a legitimacy necessary to facilitate success. For example, in Indonesia in 1998, following the downfall of Suharto, changes to the Code of Criminal Procedure were initiated in pursuit of a "reformasi era of democracy and political reform." 58

Success, however, is not always guaranteed. Even in comparatively stable regions such as Europe, where dangers associated with conquest and colonialism are largely absent and proposed reforms have been organically

terror and hopelessness among pro-independence supporters. Rimmer $\&$ Tomaras, supra note 46 .

55. Peter Broderick et al., Legal History and the Rule of Law in Timor-Leste 21 (Stanford L. Sch. Rule of L. Program, Working Paper, 2013), https://law.stanford.edu/wpcontent/uploads/2018/04/Legal-History-and-the-Rule-of-Law-in-Timor-Leste.pdf [https:/ /perma.cc/YK4P-8SEX]; see also Access to Justice Brief: Legal Assistance in Timor-Leste, COUNTERPART INT'L 1, 8 (2014), https://www.counterpart.org/wp-content/uploads/ 2015/10/ENG-Legal-Aid-Assessment.pdf [https://perma.cc/33NP-Y2W4] [hereinafter Access to Justice Briefl. A complex land title system, the product of Portuguese and Indonesian occupation, was a major source of conflict in 2006-2007. Many of the titles issued by both occupiers turned out to be fraudulent. It was estimated that, after 1999, only approximately $4.7 \%$ of land had clear title and approximately $50 \%$ of houses were illegally occupied. See James Scambary, Anatomy of a Conflict: The 2006-2007 Communal Violence in East Timor, 9 CONFLCT, SEC. \& DEV. 265, 276 (2009).

56. Geoffrey Robinson, East Timor Ten Years On: Legacies of Violence, $70 \mathrm{~J}$. Asian STud. 1007, 1007 (2011).

57. Stromseth ET AL., supra note 16 , at 4 . Legal culture is defined by Lawrence M. Friedman as the "ideas, values, expectations and attitudes towards law and legal institutions, which some public or some parts of the public holds." Lawrence M. Friedman, The Concept of Legal Culture: A Reply, in Comparing Legal Cultures 33, 34 (David Nelken ed., 1997). Werner Menski expands on this idea, arguing that any discussion about whether law is a universal phenomenon is doomed from the start because there is no methodology or uniform definition of law. For example, even simple societies can be considered to have law if the overriding principle of such law is to avoid disputes and legal institutions at all costs. See Werner Menski, Comparative Law in a Global Con. teXt: The Legal. Systems of Asia and Africa 34 (2d ed. 2006).

58. Robert R. Strang, "More Adversarial, but Not Completely Adversarial": Reformasi of the Indonesian Criminal Procedure Code, 32 FordHAM INT'L L.J. 187, 202 (2008). 
driven, legal system reform has been a complicated endeavor. Loyalty to Italian legal culture was the alleged reason prosecutors resisted 1989 reforms to the Italian Code of Criminal Procedure that were intended to introduce adversarial features into a historically inquisitorial system. ${ }^{59}$ Similarly, efforts by French President Nicolas Sarkozy in 2009 to eliminate the role of the Investigating Judge in criminal proceedings and transfer investigative powers to prosecutors were met with intense opposition by critics who argued that the proposed reforms ran counter to French values and history and reflected Sarkozy's excessive fondness for Britain and the United States. 60

Practitioners may also resist reform for their own reasons. John $\mathrm{H}$. Langbein believes that even before Comparative Law entered the mainstream academic arena, cultural differences were not the true reason for reluctance by common law practitioners to engage with other legal systems. Instead, he states that it was lawyers' vested interests, including-and perhaps, especially-their financial interests, in maintaining control of court proceedings that prevented system change. ${ }^{61}$

Legal system reform is perhaps most successful when changes are consistent with aspects of the system that had previously been in place. In Russia, juries were reintroduced in 2002 as part of the new Code of Criminal Procedure, which was adopted in order to shift the legal system away from one that had maintained an overt prosecutorial bias and Soviet pri-

59. See William T. Pizzi \& Mariangela Montagna, The Battle to Establish an Adversarial Trial System in Italy, 25 MiCH. J. INT'L L. 429, 430-31 (2004); see also Riccardo Montana, Adversarialism in Italy: Using the Concept of Legal Culture to Understand Resistance to Legal Modifications and Its Consequences, 20 Eur. J. CRIME CRIM. L. \& CRIM. Just. 99, 102 (2012). In 1988, the Italian Parliament introduced a new Code of Criminal Procedure (Code) that inserted adversarial features into a system that, until that point, had been strongly inquisitorial. When the Constitutional Court invalidated sections of the new Code, Parliament amended the Constitution, giving the accused protections that mirrored those in adversarial systems. Twelve years after the new Code was enacted, Parliament amended the Code once again to reflect the newly accrued panoply of constitutional rights of the defense. Id. at 104.

60. See Bruce Crumley, Will France Americanize Its Legal System?, Time MaG. (Jan. 9, 2009), http://content.time.com/time/world/article/0,8599,1870443,00.html [https:// perma.cc/XR6U-9S3K]; Lara Marlowe, Sarkozy's Reform of French Justice System Causes Outcry, IRISH TIMES (Jan. 19, 2019), https://www.irishtimes.com/news/crime-and-law/ sarkozy-s-reform-of-french-justice-system-causes-outcry-1.1235159 [https://perma.cc/ NB4X-8UWN]; French Criminal Justice: A Delicate Judgment, Economist (Sept. 10, 2009), https://www.economist.com/europe/2009/09/10/a-delicate-judgment [https:// perma.cc/5ZNW-8F6V]. France's pride in its Civil Code dates back to Napoleon himself, who said: "My true glory is not to have won forty battles . . ; what nothing can efface, what will endure forever, is my Civil Code." Alain A. Levasseur, The Conference: Why?, 51 LoY. L. Rev. 1, 1 (2005). Germany and Italy, in 1974 and 1988 respectively, eliminated the role of the Investigating Judge with greater ease. See StePHEN C. Thaman, Comparative Criminal Procedure: A Casebook Approach 16 (2002).

61. John H. Langbein, Cultural Chauvinism in Comparative Law, 5 CARdozo J. INT'L \& COMPAR. L. 41, 48 (1997). For reasons similar to those articulated by Langbein, Robert Strang argues that common law systems, especially as practiced in the United States, are not likely to adopt inquisitorial aspects of civil law criminal justice systems due to a history of hostility for the inquisitorial system. Strang, supra note 58, at 192. 
macy of the state over the individual. ${ }^{62}$ However, juries were already familiar to scholars of the Russian legal system because they had been introduced in 1864 by Alexander II, although they were later abolished by the Bolsheviks in 1917. ${ }^{63}$ Moreover, juries had been used in nine administrative regions of Russia since 1993.64

When legal system change takes place in proximity to conflict, complexities are introduced that render transitions even more difficult. This is especially true when aspects of the legal system were implicated in the conflict. Linkages between laws and conflict have been recognized by both academics and practitioners who have actively worked in peacekeeping missions. ${ }^{65}$ They are also recognized in the Brahimi Report, which addresses the need for legal reform when pre-conflict systems have lost legitimacy, ${ }^{66}$ and by the European Commission, ${ }^{67}$ which acknowledges that ethnic and religious inequalities within justice systems can lead directly to conflict.

\section{The Role of International Advisers and the Question of Agendas}

Post-conflict reconstruction frequently involves external advisers. Especially in situations in which conflict has resulted in reduced levels-or a complete absence-of legal expertise, external advisers are often called upon to provide knowledge and experience lacking in conflict-affected settings. A number of international organizations and regional and national agencies-including the United Nations Development Programme, the European and African Unions, the United States Agency for International Development, the Danish International Development Agency, and the Department for International Development in the United Kingdomengage in Rule of Law programming in post-conflict settings. ${ }^{68}$

62. Stephen C. Thaman, The Resurrection of Trial by Jury in Russia, 31 STAN. J. INT'L L. 61, 63 (1995); see also Catherine Newcombe, Russian Criminal Procedure, in Criminal Procedure: A Worldwide Study 397, 397 (Craig M. Bradley ed., 2d ed. 2007).

63. Nick Holdsworth, Russia Scraps Right to Jury Trial, Telegraph (Dec. 12, 2008, 4:43 PM), https://www.telegraph.co.uk/news/worldnews/europe/russia/3725300/Russia-scraps-right-to-jury-trial.html [https://perma.cc/CCW3-3XCQ].

64. Newcombe, supra note 62 , at 398.

65. See Stromseth et Al., supra note 16 , at 178.

66. Brahimi Report, supra note 8 , 9979,81 .

67. See generally Joint Staff Working Document, supra note 7 .

68. The multiple donors active in post-conflict settings can result in competing or overlapping programming. For an example of challenges associated with donor coordination in Haiti, see Janice M. Stromsem \& Joseph Trincellito, Building the Haitian National Police: A Retrospective and Prospective View, in HaITI PAPERS 1, 8 (Trinity Coll. D.C., Haiti Program Ser. No. 6, 2003). Legal assistance provided by agencies from the same country is not always coordinated smoothly. For example, although the U.S. Agency for International Development (USAID) and the Office of Overseas Prosecutorial Development Assistance (OPDAT) are major U.S. actors in Rule of Law work, they do not necessarily support the same agendas. USAID's developmental approach has historically emphasized the goal of building institutions that strengthen democracies and economies, while OPDAT tends to focus on reducing and eliminating criminal activity that originates in other countries and makes its way to the United States. See Máximo 
Tom Carothers outlines four broad clusters of historical agendas in Rule of Law assistance: democracy promotion, human rights and social justice movements, economic development, and international law enforcement. ${ }^{69}$ Each agenda is promoted by agencies and organizations with specific interests in it. ${ }^{70}$ Agendas are not always transparent, however. Socalled "failed laws" or "failed legal systems" may be used as pretexts to reconfigure agendas for funders' tactical, political, or financial gain. ${ }^{71}$ Failed systems may also be viewed as opportunities for reform by external advisers and activists who deem local laws to be culturally backwards or economically regressive. ${ }^{72}$ In some cases, it has been suggested that it was the convenience of peacekeepers, who were unfamiliar with indigenous systems and therefore unable or unwilling to engage with them, that justified systemic change. ${ }^{73}$

The role of external advisers has evolved over time and has not been free from controversy. During the process of legislative reform in post-war Germany, conflicts arose among the four Allied powers and their German counterparts due to competing national agendas and an almost complete lack of familiarity with all aspects of German life. ${ }^{74}$ In Cambodia, where post-conflict reconstruction efforts required decisions about which legal

Langer, Revolution in Latin American Criminal Procedure: Diffusion of Legal Ideas from the Periphery, 55 Am. J. Compar. L. 617, 658 (2007).

69. Thomas Carothers, The Many Agendas of Rule of Law Reform in Latin America, in Rule of Law in Latin America: The international Promotion of Judicial Reform 7-8 (P. Domingo \& R. Sieder eds., 2001).

70. But see Jonathan M. Miller, A Typology of Legal Transplants: Using Sociology, Legal History and Argentine Examples to Explain the Transplant Process, 51 Am. J. Compar. L. 839,845 (2003) ("Perhaps the central conclusion to arise from the failed law and development projects of the 1960's and '70's was that the domestic dynamics of the recipient are almost always far more relevant to the course of a [legal] transplant than the role of the donor.").

71. Jorge L. Esquirol, The Failed Law of Latin America, 56 Am. J. Compar. L. 75, 79 (2008).

72. Controversially, Lan Cao argued that since culture plays a significant role in aiding or obstructing economic development, the field of law and development should pursue purposive cultural change. Cao states,

[a]s slippery a concept as culture may be and as complex and controversial as

the notion of culture change undoubtedly is, particularly given the history of colonialism, I argue that we must enter the cultural milieu and ask whether certain cultural attributes in a given society are an impediment to that society's economic development. . . L Law and development assistance must therefore con-

front even issues that seem to be part of a country's proclaimed cultural identity. Lan Cao, Culture Change, 47 VA. J. INT'L L. 357, 358 (2007).

73. Bruce M. Oswald, Model Codes for Criminal Justice and Peace Operations: Some Legal Issues, 9 J. Conflict \& SEC. L. 253, 260-61 (2004). Oswald explains that "[a]ny changes to ... law and procedure should be restricted to that which is necessary and reasonable." Id. at 262. The ethics of engaging in legal system reform when there is no legal basis is discussed by Allen Buchanan. See Allen Buchanan, From Nuremburg to Kosovo: The Morality of Illegal International Legal Reform, 111 ETHICs 673, 674 (2001). The author criticizes illegal reform, explaining that "what some hail as progress others decry as illegal acts that threaten the rule of law, betray a lack of sincerity regarding fidelity to law, and manifest a disturbing willingness to impose subjective, personal moral standards on others." Id.

74 . Loewenstein, supra note 20 , at 740. 
system should serve as the basis for new legislation, conflicts between Khmer and international advisers, and among advisers from common law and civil code systems, initially hampered efforts to reestablish the Rule of Law. ${ }^{75}$

Although contributions by international advisers may inevitably result in inadvertent influences from their own legal backgrounds, ${ }^{76}$ scenarios in which advisers view collapsed systems as "clean slates," or tabula rasa, that provide possibilities for creating legal orders from scratch are more problematic. $^{77}$ In one troubling case, a legal adviser opined:

[1]nternational actors should carefully analyze the culture, circumstances and needs of the state in question and, . . . construct the most suitable legal order.

...

In the context of state-building, not only must one successfully create a legal system that is theoretically functional, but one must then teach this system to a country of lawyers, judges, and legal personnel that have, up to that point in their legal existence, conceived of law and legal practice differently. ${ }^{78}$

A more ethical role for legal advisers in post-conflict reconstruction efforts is proposed by Louis Aucoin, who advocates respect for the sover-

75. Corbin Lyday \& Jan Stromsem, USAID, Rebuilding the Rule of Law in PostConflict Environments 15 (2005); see also Kong Phallack, Overview of the Cambodian Legal and Judicial System, in INTRODUCTION TO CAMBODIAN LAW, supra note 32, at 7, 17. "The current legal system is a hybrid legal system, which is an amalgamation of Cambodian customs, the French based legal system (an influence from French colonization), and the common law system, which is an influence arising from foreign aid assistance to legal and judicial reform in Cambodia." Id. at 8.

76. The contributions of international advisers to post-conflict reconstruction processes in Cambodia have introduced influences from Vietnam, Japan, France, and various common law systems. Menzel, supra note 32, at 482-83.

77. Nicolas Lemay-Hebert, The "Empty Shell" Approach: The Setup Process of International Administrations in Timor-Leste and Kosovo, Its Consequences and Lessons, 12 INT'L Stud. Persp. 190, 195 (2011). In 1999, Xanana Gusmão, leader of the Timorese revolution against Indonesian occupation, said: "we don't feel very comfortable with some people acting like kings of East Timor, coming here to impose their models . . .." Id. at 203. Later, Samantha Power recounted a scenario in which Xanana Gusmão had occasion to receive advice from Cambodian Prime Minister Hun Sen, another political leader who had lived through a U.N. transitional administration. SAMANTHa POWER, Chasing the Flame: Sergio Vieira de Mello and the Fight to Save the World 299 (2008). While standing in line to enter a reception hosted by President Bill Clinton at the Metropolitan Museum of Art, Hun Sen warned Gusmão about U.N. involvement. The warning proved justified when Gusmāo returned to Timor and learned that, under Resolution 1272, a transitional administration had been created for Timor-Leste, delegating "all legislative and executive authority . . . to a foreign U.N. administrator who would run East Timor for at least fifteen months." Id. at 300 (citations omitted). After a significant percentage of Timor's population had lost their lives in pursuit of independence, the terms of Resolution 1272 were not welcome news. Id.

78. Dan E. Stigall, Comparative Law and State-Building: The "Organic Minimalist" Approach to Legal Reconstruction, 29 Loy. L.A. INT'L \& Compar. L. Rev. 1, 18, 22 (2007). The "Empty Shell" approach is also criticized by Bruce M. Oswald as a return to the doctrine of terra nullius, which is based on the idea that territory occupied by another state is inhabited by people who have no social or political organization. Oswald, supra note 73 , at 261 . 
eign right of indigenous actors to select legal and constitutional models from an array of options presented by advisers with backgrounds in Comparative Law. ${ }^{79}$

Traditional North-South development models, in which advisers from the global North provide advice to recipients in the global South, have come under attack in recent years since they tend to perpetuate colonial power imbalances and place countries in the southern hemisphere in positions of dependency. More recent South-South cooperative models, in which members of the global South share experiences and lessons learned with members of other countries in the southern hemisphere, are meant to provide expressions of solidarity among developing countries. ${ }^{80}$ SouthSouth cooperative models may also enhance legitimacy among recipient communities since they do not carry the stigmas associated with colonization. $^{81}$

\section{Applicable Legal Frameworks}

Because legality is linked to perceptions of legitimacy in local populations, establishing a valid legal basis for legal system reform is important in post-conflict settings. Laws introduced by external legal advisers will have little chance of success if they are believed to have been imposed illegally. Applicable legal bases will depend on the circumstances in which reform is undertaken.

\section{A. Frameworks During Occupation}

The governing legal frameworks of occupation are set forth in the 1907 Hague Convention and the Fourth Geneva Convention. ${ }^{82}$ Article 43 of the 1907 Hague Convention imposes two obligations on an occupying

79. See generally Louis Aucoin, The Role of International Experts in Constitution-Making: Myth and Reality, 5 GEO. J. INT'L AFF. 89 (2004). This approach is mirrored by Corbin Lyday and Jan Stromsem who recommend that U.S. advisers not write new codes, but rather advise and comment local officials in the reform process. See LydAY \& STROMSEM, supra note 75, at 15-16.

80. Silvia López Cabana, Chronology and History of South-South Cooperation: An Ibero-American Contribution 9-10 (Ibero-Am. Programme for the Strengthening of SouthSouth Cooperation, Working Paper No. 5, 2014), https://www.segib.org/wp-content/ uploads/Chrono-South-South2014.pdf [https://perma.cc/8AUC-X6P4].

81. See Langer, supra note 68, at 661-62. Drawing upon gift theory, previously confined to analyses of Western foreign aid, at least one scholar has criticized South-South development models as discursively constructing the "aid" element of South-South development cooperation. Emma Mawdsley argues that euphemistic, Southern cooperative models obscure contested subnational politics of development and growing differences among G77 nations. Her analysis focuses on "the ways in which Southern development actors represent a challenge to the dominant aid paradigm, transgressing dominant cultural categories and social hierarchies of who gives and who receives," refusing to take claims of South-South solidarity and mutual benefit at face value. See generally Emma Mawdsley, The Changing Geographies of Foreign Aid and Development Cooperation: Contributions from Gift Theory, 37 Transactions InSt. Brit. Geographers 256 (2012).

82. Occupation and International Humanitarian Law: Questions and Answers, INT'L COMM. RED CROSS (Apr. 8, 2004), https://www.icrc.org/en/doc/resources/documents/ misc/634kfc.htm [https://perma.cc/LE7A-XG5B]. 
power: "(a) to restore and ensure, as far as possible, public order and life in the occupied territory; [and] (b) to respect the laws in force in the occupied territory unless an 'empêchement absolu' exists." 83 In general, Article 43 is interpreted to mean that an occupying power must maintain the laws of the occupied territory at the time of occupation in place to the extent possible. However, given the occupying power's concomitant responsibility to restore and ensure public order and life, it is generally understood that the preexisting legal system can be modified through new legislation when a necessity arises. ${ }^{84}$ Any change made to the legal system deemed necessary by the occupying power only applies during actual occupation, "unless a returning territorial sovereign" elects to keep it intact. ${ }^{85}$

Article 64 of the 1949 Fourth Geneva Convention outlines three circumstances under which an occupying power may suspend or repeal the existing laws of the state and enact new legislation as necessity demands: "to fulfill its obligations under the . . Convention, to maintain the orderly government of the territory, and to ensure the security of the Occupying Power." 86 Although Article 47 of this Convention permits an occupying power to suspend, repeal, or change existing law, inhabitants may not be deprived of the protections of international law. ${ }^{87}$

\section{B. Frameworks During Peacekeeping Operations}

Bruce M. Oswald examines the legality of engaging in any type of system reform outside occupation contexts and states that in almost every case, "it is the domestic law of the host state" that applies during peacekeeping operations. ${ }^{88}$ The exception is when "domestic law ... does not comply with internationally accepted standards." 89 The rationale for this principle is that all states are sovereign, and interference in their domestic lawmaking powers should only be undertaken by exception.

In some contexts, however, preexisting legal frameworks have been discredited or rejected by local populations, especially when they are linked to the conflict itself. 90 Timor-Leste, discussed above, is one example. Following the 1999 uprising against Indonesian occupiers, the continued legitimacy of Indonesian law, which had previously been applied in

83. Yoram Dinstein, Legislation Under Article 43 of the Hague Regulations: Belligerent Occupation and Peacebuilding, in OcCasional. PAPER SERIES 2, 3 (HCPR Ser. No. 1, 2004).

84. Id. at 4.

85. Id at 5.

86. Geneva Convention Relative to the Protection of Civilian Persons in Time of War art. 64, Aug. 12, 1949, 6 U.S.T. 3516, 75 U.N.T.S. 287.

87. Commentary of 1958, INT'L COMM. RED CROsS, https://ihl-databases.icrc.org/ applic/ihl/ihl.nsf/Comment.xsp?action=OpenDocument\&documentId=C4712FE71392 AFE1C12563CD0042C34A [https://perma.cc/7CV7-ZD7J] (last visited Aug. 13, 2019) (commenting on Article 47 of the Geneva Convention Relative to the Protection of Civilian Persons in Time of War).

88. Oswald, supra note 73 , at 260.

89. Id. For a discussion of ethical considerations when engaging in unfounded, legal system reform, see generally Buchanan, supra note 73 .

90. Oswald, supra note 73 , at 272 . 


\section{Timor-Leste, evaporated. 91}

When legal system reform is undertaken, international law provides only broad guidelines and does not express preference for any specific legal system over others. The Universal Declaration of Human Rights, many provisions of which have been incorporated into customary international law and are therefore binding on all countries, ${ }^{92}$ requires only that tribunals be "independent and impartial" and that trials be "fair and public."93 The International Covenant on Civil and Political Rights (ICCPR), binding on countries that are party to it, similarly requires that trials be "fair and public" and carried out by "competent, independent and impartial tribunal[s] established by law." 94 Language in the European Convention on Human Rights is almost identical, requiring "a fair and public hearing within a reasonable time by an independent and impartial tribunal established by law."95

Fair trial rights in the African Union are more specific. ${ }^{96}$ Such rights require "a fair and public hearing by a legally constituted[,] competent, independent[,] and impartial judicial body," 97 and include:

(a) equality of arms between the parties to the proceeding, whether they be administrative, civil, criminal, or military; (b) equality of all persons before any judicial body without any distinction whatsoever as regards race, color, ethnic origin, sex, gender, age, religion, creed, language, political or other convictions, national or social origin, means, disability, birth, status or other circumstances; ${ }^{98}$ (c) equality of access by women and men to judicial bodies and equality before the law in any legal proceedings; (d) respect for the inherent dignity of the human person, especially of women who participate in legal proceedings as complainants, witnesses, victims or accused; (e) adequate opportunity to prepare a case, present arguments and evidence and to challenge or respond to opposing arguments or evidence; $(f)$ an entitlement to consult and be represented by a legal representative or other qualified persons chosen by the party at all stages of the proceedings; (g) an entitlement to the assistance of an interpreter if he or she cannot understand or speak the language used in or by the judicial body; (h) an entitlement to

91. See discussion supra Section I.F.

92. Hurst Hannum, The UDHR in National and International Law, HEALTH \& HUM. RTs., 1998, at $144,145$.

93. G.A. Res. 217 (III) A, Universal Declaration of Human Rights, art. 10 (Dec. 10, 1948).

94. International Covenant on Civil and Political Rights art. 14, Dec. 16, 1966, 999 U.N.T.S. 171

95. Convention for the Protection of Human Rights and Fundamental Freedoms art. 6, Nov. 4, 1950, E.T.S. No. 5, 213 U.N.T.S. 221 [hereinafter European Convention on Human Rights].

96. Principles and Guidelines on the Right to a Fair Trial and Legal Assistance in Africa, Afr. Comm'N Hum. \& People's RTs. 1, 1-2 (2003), https://www.achpr.org/legalinstruments/detail?id=38 [https://perma.cc/99VU-UJM6] [hereinafter African Principles $\&$ Guidelines].

97. Id. at 1 .

98. Although sexual orientation is protected in a number of European conventions, similar protections do not exist in the African Union. Compare, e.g., Treaty Establishing the European Community art. 13, Dec. 24, 2002, 2002 O.J. (C 325) 151, with African Principles $\&$ Guidelines, supra note 96 , at 1-2. 
have a party's rights and obligations affected only by a decision based solely on evidence presented to the judicial body; (i) an entitlement to a determination of their rights and obligations without undue delay and with adequate notice of and reasons for the decisions; and ( $j$ ) an entitlement to an appeal to a higher judicial body. ${ }^{99}$

Article 8 of the American Convention on Human Rights essentially mirrors language of the ICCPR and the European Convention on Human Rights with the important addition of an "inalienable right to be assisted by counsel provided by the state, paid or not as domestic law provides, if the accused does not defend himself personally or engage his own counsel within the time period established by law."100

The international legal framework's flexibility is reflected in the Secretary General's report, The Rule of Law and Transitional Justice in Conflict and Post-Conflict Societies. The report specifies that the normative foundation for the United Nations' promulgation of the Rule of Law consists of the U.N. Charter and the four pillars of the modern international law system. ${ }^{101}$ These guidelines accommodate the full range of member states' legal systems, whether they are based on common law, civil law, Islamic law, or other legal traditions, and are designed to provide the legitimacy that legal transplants from individual countries cannot. In other words,

these norms and standards bring a legitimacy that cannot be said to attach to exported national models which, all too often, reflect more the individual interests or experience of donors and assistance providers than they do the best interests or legal development needs of host countries. ${ }^{102}$

\section{Which Legal System? A Comparative Approach}

Even when well trained in principles of public international law, and despite best intentions, international legal advisers-a large number of whom are from Western countries-who are deployed to assist in post-conflict reconstruction processes often suffer from a lack of training in legal systems other than their own. ${ }^{103}$ Because of this, the latitude provided by

99. African Principles \& Guidelines, supra note 96 , at 2 .

100. American Convention on Human Rights art. 8(2)(e), Nov. 22, 1969, 1144 U.N.T.S. 123 , O.A.S.T.S. No. 36.

101. U.N. Secretary-General, The Rule of Law and Transitional Justice in Conflict and Post-Conflict Societies, 9 9, U.N. Doc. S/2004/616 (Aug. 23, 2004) [hereinafter The Rule of Law and Transitional Justice in Conflict and Post-Conflict Societies]. The four pillars are: "international human rights law; international humanitarian law; international criminal law; and international refugee law." Id.

102. Id. 910.

103. In a recent article, Theresa Kaiser-Jarvis reports that "[f]orty-four percent of lawyers admitted to a U.S. state bar in 2000 dealt with clients from outside the U.S. or with cross-border issues during the 2006-2007 calendar year." Theresa Kaiser-Jarvis, Preparing Students for Global Practice: Developing Competencies and Providing Guidance, $67 \mathrm{~J}$. LEGAL EDUC. 949, 950 (2018). And that "more than sixty percent of lawyers in large firms, corporations, legal services offices, and public defender offices report[ed] that they solved global legal issues during their sixth year of practice." Id. But despite these numbers, it is uncommon for U.S. law schools to offer courses in the laws of other countries, which would prepare students for a global legal practice. Id. Kaiser-Jarvis 
international law with respect to choice of legal systems is not necessarily a

recommends that law students "gain familiarity with a legal system other than the common law" system, which is practiced exclusively in only "twenty-three of the United Nations' 192 member states." Id. at 956.

William T. Pizzi offers a similar outlook, stating that Americans need a new "perspective on [the American] trial system . . . because an American legal education is very narrow in its focus. ... Students become familiar with American statutes, regulations, decisional law, and the American trial system. Other legal traditions are ignored." WILliam T. Pizzi, Trials Without Truth: Why Our System of Criminal Trials Has Become an Expensive Failure, and What We Need to Do to Rebuild It 90 (1999).

Academic myopia with respect to Comparative Law is not an exclusive problem of the United States. In 2000, a French law professor submitted a report to the Minister of Education and Research denouncing the poor status of Comparative Law in France and calling for the creation of comparative law studies. Bénédicte Fauvarque-Cosson, Development of Comparative Law in France, in THE OXFord HANDBOOK OF COMPARATIVE LAW 29, 43 (Mathias Reimann \& Reinhard Zimmermann eds., 2d ed. 2019).

Mere academic disinterest in other legal systems can morph into outright hostility in the political arena. In one of his books, Justice Stephen Breyer recounts efforts by elected officials in 2004 to restrict judicial determinations regarding the meaning of laws of the United States, stating that such determinations should not be based in whole or in part on judgments or laws of other countries. Stephen Breyer, The Court AND the World: American Law and the New Global Rfalitites 238 (2015). A sponsoring member of the House of Representatives also proposed that judges who deliberately violated the legislation should be subject to impeachment. Id. at 334; see also Appropriate Role of Foreign Judgments in the Interpretation of American Law: Hearing on H. Res. 568 Before the Subcomm. on the Constitution, 108th Cong. 42 44 (2004) (statement of Rep. Jerrold Nadler) (quoting Rep. Tom Feeney); Steven G. Calabresi, "A Shining City on a Hill": American Exceptionalism and the Supreme Court's Practice of Relying on Foreign Laws, 86 B.U. L. REv. 1335, 1337 (2006); Daniel A. Farber, The Supreme Court, the Law of Nations, and Citations of Foreign Law: The Lessons of History, 95 CAL. L. Rev. 1335, 1336 (2007); Mark Tushnet, When Is Knowing Less Better than Knowing More? Unpacking the Controversy over Supreme Court Reference to Non-U.S. Law, 90 MiNN. L. REv. 1275, 1277 (2006); Jeremy Waldron, Foreign Law and the Modern Ius Gentium, 119 HARV. L. REv. 129, 132 (2005); Justices Antonin Scalia, Assoc. Justice, U.S. Supreme Court, \& Stephen Breyer, Assoc. Justice, U.S. Supreme Court, Discussion at the American University Washington College of Law: Constitutional Relevance of Foreign Court Decisions (Jan. 13, 2005), https://www.c-span.org/video/?185122-1/constitutional-relevance-foreign-court-decisions [https://perma.cc/R3MQ-VD3C] (Justices Scalia and Breyer debating the merits of citing foreign law, with Justice Breyer arguing in favor and Justice Scalia arguing against).

In Europe, the Comparative Law methodology is widely accepted. Bodies such as the European Court of Justice and the Venice Commission routinely compare national laws of member states when creating jurisprudence and rendering advisory opinions. See Koen Lenaerts \& Kathleen Gutman, The Comparative Law Method and the European Court of Justice: Echoes Across the Atlantic, 64 AM. J. Compar. L. 841, 844 (2016); see also, e.g., Opinion of the European Commission for Democracy Through Law on the Provisions Relating to Political Prisoners in the Amnesty Law of Georgia, at 4 (Mar.9, 2013), https:// www.venice.coe.int/webforms/documents/default.aspx?pdffile $=$ CDL-AD(2013)009-e

[https://perma.cc/X7SH-V5WB]. Moreover, an advisers' lack of familiarity with other legal systems can raise ethical questions about their work. Stromseth and Kleinfeld directly address the question of whether legal system reform carried out by external advisers constitutes a form of imperialism or neocolonialism. KLEINFELD, supra note 5, at 37-58; STROMSETH ET AL., supra note 16, at 1-17. Menski is especially critical of those who pay "lip service . . . to social influences on law" but still hold the presumption that "progressive initiatives should come from the West." MENSKI, supra note 57, at 48. Menski argues that this practice "ultimately den[ies] non-European legal cultures the capacity and the chance to develop on their own terms." Id. 
benefit. ${ }^{104}$ Too often advisers' ignorance about other legal systems cause them to default unwittingly into chauvinistic preferences for their own systems and soapboxes, advocating universality. ${ }^{105}$ This Article suggests that a background in Comparative Law should be a prerequisite for anyone engaged in legal system reform.

Although scholars differ as to the date Comparative Law emerged as a discipline, ${ }^{106}$ virtually all agree that the field is now evolving rapidly and achieving increased prominence, in large part because of the Europeanization of law and globalizing trends in contemporary life. ${ }^{107}$ Opinions about which systems should be included in the field have also shifted over generations. For example, early scholars tended to focus on Western systems to the exclusion of others ${ }^{108}$ or to mislabel non-Western systems. ${ }^{109}$ Colin Picker finds darker motives for comparatists' preferences for Western legal systems, arguing that some comparatists simply view non-Western systems

104. Gaps in existing legal frameworks can provide opportunities for advocates to create legal protections without violating either international or domestic law. For example, in countries in Southeast Asia, where laws do not explicitly identify time frames for the attachment of legal rights to representation, human rights advocates have successfully introduced norms authorizing defense counsel to begin representing accused persons immediately upon arrest. Interview with Sanjeewa Liyanage, Int'l Program Dir., Int'l Bridges to Justice, in Nyaung Shwe, Myan (Aug. 5, 2019).

105. Menski asks, "to what' extent globalisation means harmonisation or even global uniformisation of laws, rather than glocalisation or global pluralism"? He states that the idea of creating a universal legal order draws students to international law courses. But it is questionable whether universalization is an appropriate response to the multiple impacts of globalization. MENSK, supra note 57, at 38. Menski also argues that globalization "sits uneasily with [the] recognition of legal diversity." Id. at 39 (critiquing René David and John E.C. Brierley). Perspectives on universality may be shifting away from the declining influence of the United States and its legal system, and toward the increasing influence of the "BRIC States," composed of Brazil, Russia, India, and China. See Sean Butler, Visions of World Order: Multipolarity and the Global 'Constitutional' Framework, in EUROPEAN SOCIETY OF INTERNATIONAL LAW, at 1, 3 (ESIL Conference Paper Ser. No. 1, 2018).

106. Charles Donohue argues that traces of Comparative Law can actually be found in the ancient world. Charles Donohue, Comparative Law Before the Code Napoléon, in The OXFORD HANDBOOK OF COMPARATIVE LAw, supra note 103, at 4.

107. Mathias Reimann \& Reinhard Zimmermann, Preface to The OxFord Handbook of Comparative Law, at vii (Reimann \& Zimmermann eds., 2d ed. 2019).

108. Historically, Comparative Law analyzed only civil and common law, largely because Western countries carried out most international business transactions, and it was in their commercial interest to control the rules of the game. See 48 Guy I. Seidman, The New Comparative Civil Procedure, in The Dynamism of Civil Procedure-Global Trends AND Developments 19 (Colin B. Picker \& Guy I. Seidman eds., 2016).

109. As recently as 1985 , Rene David and John E.C. Brierley compared the RomanoGermanic family, Socialist laws, the common law, and "other conceptions of law and the social order," including Sharia law, India, laws of the far East, and the laws of Africa and Malagasy. René David \& John E.C. Brierley, Major Legal Systems in the Worid Today vii-xii (3d ed. 1985). In 1994, Mary Ann Glendon, Michael Wallace Gordon, and Christopher Osakwe compared various aspects of the civil code and common law traditions. See generally Mary ANN Glfndon Et al., Comparative Legal Tradrtions (2d ed. 1994). H. Patrick Glenn notably distanced himself from these titles and categories. His book covers, in balanced fashion, the chthonic, Talmudic, civil, Islamic, common law, Hindu, and Asian legal traditions, and argues persuasively in favor of preservation of, and respect for, each system. H. Patrick Glenn, Legal. Traditions of the World: SustainaBle Diversity in Law (Oxford Univ. Press 5th ed. 2014). 
negatively, believing they are less sophisticated and therefore less able to provide useful contributions. He states:

Sometimes what may be going on in the background is a result of a conflation of a distaste for the other state's culture or politics with the parent state's approaches and hence an unwillingness to even consider the potential benefits of comparative analyses involving the legal system of those states. ${ }^{110}$

Werner Menski tends to agree, stating: "Global legal debates on human rights and religious law circle uncomfortably around the often unspoken but systematic denial that anything useful could be learnt from non-Western socio-legal traditions." 111

But this reductive perspective may be on its way out. Interest in nonWestern legal systems has increased in recent years. Funders, aid organizations, and academics are now more willing to examine whether non-Western systems can make useful contributions during legal reform efforts. ${ }^{112}$ Non-Western systems may be of particular use in conflict contexts, where state-sponsored legal mechanisms may have completely disappeared or been discredited. ${ }^{113}$

\section{Toward a Comparative Problem-Solving Model During Post- Conflict Reconstruction Processes}

As a strategy for avoiding cut-and-paste methodologies during legitimate, Rule of Law reform processes, ${ }^{114}$ this Article proposes a "toolkit approach." The approach begins with conflict assessment, then disaggregates the preexisting legal system that may have contributed to the conflict, and ends with a comparative examination of other systems whose component parts might contribute to peace-building.

110. 48 Colin B. Picker, Comparative Law as an Engine of Change for Civil Procedure, in The Dynamism of Civil Procedure-Global Trends and Developments, supra note 108, at 45,54 .

111. Menski, supra note 57, at 30. Menski goes on to say that if scholars took the time and made the effort to study Asian and African perspectives "from inside," so-called universal, eurocentric assumptions about what law is would become "impossible to maintain." Id. at 32 .

112. See, e.g., Jan Stromsem, USAid, Africa Regional Rule of Law Status Review 58 (2009) ("It is becoming increasingly understood that for sustainability, donor programs must take into account customary and religious systems prevalent in all countries of the region. Albeit still on a limited basis, the international community is beginning to reconsider its position with respect to traditional and customary systems.").

113. See Kirsti Samuels, Rule of Law Reform in Post-Conflict Countries: Operational Initiatives and Lessons Learnt, in Social Development Papers 1, 18 (World Bank, Conflict Prevention \& Reconstruction Ser. No. 37, 2006).

114. Whether reading for background knowledge or in search of a blueprint, Noah Feldman remembers that, while flying to Baghdad in his capacity as Senior Constitutional Adviser to the Coalition Provisional Authority, "most of his fellow advisers were reading books on the reconstruction of Germany and Japan in the wake of the Second World War." Jeff Bridoux, American foreign Policy and Postwar Reconstruction: COMPARING JAPAN AND IRAQ 132 (2011). 


\section{A. Conflict Mapping}

Conflict mapping is a relatively new field that crosses boundaries between political science, where it was traditionally situated, and law. Conflict mapping differs from a needs assessment or baseline study; it involves "separating [and analyzing] the constituent parts of a conflict, such as the historical background, parties, issues involved, and [the] context" in which the conflict emerged. ${ }^{115}$ During post-conflict, legal system reform, mapping the local system is recommended as part of the conflict analysis. ${ }^{116}$ Conflict mapping requires an interdisciplinary team-including anthropologists, political scientists, and conflict management or organizational specialists-to work alongside national experts, especially those who were excluded from former power structures, to complement a cadre of judges, prosecutors, and other legal system actors. ${ }^{117}$

The mapping process, which examines links between the preexisting legal system and the root causes of conflict, should yield a list of legal issues to be addressed and set the stage for a comparative analysis of the contributions other legal systems could make to resolve those issues. ${ }^{118} \mathrm{~A}$ number of organizations involved in legal reform, including the European Commission $^{19}$ and the Instituto de Estudios Comparados en Ciencias Penales de Guatemala (Institute for the Comparative Study of Criminal Law in Guatemala), advocate for problem-solving approaches that initiate legal reform by first identifying the specific problems to be addressed. ${ }^{120}$

115. Wendy S. Betts \& Gregory Gisvold, Conflict Mapping: Innovation in International Responses in Post-Conflict Societies, HuM. RTs. BrIEF, Spring 2003, at 24, 25. Conflict mapping was carried out in Timor-Leste following the 2006-2007 violence that broke out among various ethnic and community groups, partly as a result of complex and contradictory land title laws. See Scambary, supra note 55, at 276-78.

116. See generally Vivienne O'Connor, Mapping the Justice System and Legal FrameWORK IN A CONFLICT-AFFECTED COUNTRY (2015). Wilita D. Sanguma argues that the international community's "inability to understand ... the different factors . . . fueling the overall conflict in Congo" was responsible for its poor peacebuilding performance. Wilita D. Sanguma, Re-evaluating Peacebuilding in the Democratic Republic of Congo: A Case Study in Dongo 29 (Nov. 2012) (unpublished MIS thesis, University of San Francisco) (on file with the University of San Francisco's Digital Repository of Master's Theses).

117. USAID's approach to a conflict-oriented Rule of Law assessment marries strategies of a general Rule of Law country analysis, which determines the status of five essential elements of a well-functioning justice system-order and security, legitimacy, fairness, checks and balances, and effective application-with a conflict assessment. See Gail Lecce et al., USAid, Guide to Rule of Law Country Analysis: The Rule of Law Strategic Framework 1-2, 20 (2008).

118. A type of problem-solving comparative methodology is proposed by Kent Roach, who examines the rise in wrongful convictions in Anglo-American legal systems, which has shaken public confidence in adversarial criminal justice systems. He argues that introducing reforms based on inquisitorial models could offer solutions to these problems. See Kent Roach, Wrongful Convictions: Adversarial and Inquisitorial Themes, 35 N.C. J. INT'L L. \& COM. REG. 387, 424 (2010).

119. See Joint Staff Working Document, supra note 7, at 13.

120. See Graeme Thompson, Putting Guatemala's Justice System on Trial, INT'L DEv. RsCH. CTR. (Dec. 3, 2004), https://www.idrc.ca/en/article/putting-guatemalas-justicesystem-trial [https://perma.cc/LJ2L-YAM6]. 
Since they begin by addressing root issues and then tailor recommendations to specific contexts, problem-solving models during post-conflict reconstruction are consistent with the recognition that one-size-fits-all models, sometimes referred to as "cut-and-paste" models that encourage advisers to fall back on their familiarity with their own legal systems, do not work. The Secretary General's report on The Rule of Law and Transitional Justice in Conflict and Post-Conflict Societies advocates for the abandonment of "cut-and-paste" models, ${ }^{121}$ and instead recommends using national assessments, national participation, and reference to national needs and aspirations. ${ }^{122}$ In addition to ensuring local legitimacy, a problem-solving model has the benefit of focusing on the specific goals of local communities and the specific root causes of conflict. ${ }^{123}$ Individualized problemsolving also allows power structures that supported conflict to be taken into consideration. ${ }^{124}$

\section{B. The Comparative Law Methodology}

The proposed Comparative Law approach is designed to create a toolkit for legal system advisers, expanding the range of alternatives available for consideration during post-conflict system reform. Although the practice of using Comparative Law methodologies to problem-solve is not longstanding, it has recently gained acceptance. ${ }^{125}$ However, the practice requires working knowledge of the spectrum of legal traditions.

In the context of system reform, some of the component parts of legal systems worth examining for their specific relationship to conflict include the topics discussed in the following sections.

121. See generally The Rule of Law and Transitional Justice in Conflict and Post-Conflict Societies, supra note 101.

122. Rachel Kleinfeld offers a similar perspective. She advocates for a turn away from institution-based approaches during Rule of Law reform, which often lead to "institution-modeling." KLEINFELD, supra note 5, at 11 . Kleinfeld explains that "[i]n too many countries, reformers approach program creation by looking at each legal institution or law, comparing it to its Western counterpart, and then trying to create 'improvements' until [the two] match." Id. This strategy, she argues, ignores "political and cultural pressures that deform institutions." Id.

123. See id. at 14.

124. See id. at 33; Lyday \& Stromsem, supra note 75 , at 13.

125. See Scott Dodson, The Challenge of Comparative Civil Procedure, 60 ALA. L. Rev. 133,138 (2008). Justice Stephen Breyer advocates for a comparative approach, arguing that opposition in the U.S. to considering the way judges in other countries solve similar problems is largely a political issue taken up by elected officials who believe that U.S. laws should not be based on laws of foreign institutions.

[I]f someone with a job roughly like my own, facing a legal problem roughly like the one confronting me, interpreting a document that resembles the one I look to, has written a legal opinion about a similar matter, why not read what the judge has said? I might learn from it, whether or not I end up agreeing with it. 


\section{Triers of Fact ${ }^{126}$}

A variety of options exist for making fact determinations, including the use of lay jurors, ${ }^{127}$ mixed panels of lay jurors and professional judges, ${ }^{128}$ and judges sitting either individually or in panels. ${ }^{129}$ In West Africa, lay judges make findings of fact. ${ }^{130}$ In some systems, community members with specific expertise may decide cases in conjunction with one or more judges. ${ }^{131}$ The most effective model will depend on the nature of the problem identified. For example, the use of lay juries-as opposed to judges-as triers of fact may be advisable when judicial corruption is an issue. ${ }^{132}$ But juries may not be advisable when the conflict was a result of ethnic, racial, or religious tensions because jury members could use verdicts as a form of "victors' justice." 133 Additionally, the use of lay jurors has been criticized when the issues to be decided are complex and outside the scope of an individual's everyday knowledge. ${ }^{134}$

BREYER, supra note 103 , at 240.

126. For a comprehensive comparative analysis of various models of triers of fact, see generally Valerie P. Hans, Jury Systems Around the World, 4 AnN. Rev. L. \& Soc. ScI. 275 (2008).

127. The use of lay jurors is, of course, a hallmark of common law systems. However, in recent years, lay juries have been introduced in historically inquisitorial systems, including those of Argentina, Japan, and Italy. See generally Meryll Dean, Legal Transplants and Jury Trial in Japan, 31 LEGAl. STUD. 570 (2011); Pizzi \& Montagna, supra note 59; Caitlyn Scherr, Chasing Democracy: The Development and Acceptance of Jury Trials in Argentina, 47 U. Miami InTER-AM. L. Rev. 316 (2016).

128. This is the practice in Germany. See Thomas Weigend, Germany, in CRIMINAI PROCEdURE: A Worldwide Study, supra note 62, at 243, 263. In China, "cases are heard by ... a 'collegial panel' of three jurists. . . [T]wo members of the panel are professional judges," and the third is a "people's assessor." Ira Belkin, China, in Criminal Procedure: A Worldwide StUdy, supra note 62, at 91, 103; see also Criminal Procedure Law of the People's Republic of China, CONG.-ExEC. COMM'N ON CHINA (2012), https:// www.cecc.gov/resources/legal-provisions/criminal-procedure-law-of-the-peoples-republic-of-china [https://perma.cc/CA9C-LMFD].

129. This is the traditional civil code model; one example is the Netherlands. See Art. 268 para. I Sv (Neth.); see also Pizzi, supra note 103, at 94. In France, unpaid members of local business communities, who are elected by their peers, try commercial cases. ANDREW West et AL., The French Legal System 78 (2d ed. 1998). A college of employers and a college of employees elect judges in French labor courts, or Conseil de Prud'hommes. Id. at 80 .

130. Obi N.I. Ebbe, The Unique and Comparative Features of the Criminal Justice Systems, International Law, and the United Nations Criminal Courts: A Synthesis, in CoMPARAtive and International. Criminal Justice Systems 275, 278 (Obi N.I. Ebbe ed., 3d ed. 2013).

131. This is the case in Croatia, for example, where lay judges sit with professional judges in juvenile cases. The lay judges are "teachers, professors, or other persons with relevant experience in juvenile education." Hans, supra note 126 , at 279 . Similarly, in Thailand's three specialized courts, "laypersons with expertise in the court's domain decide cases together with professional judges." Id. at 280.

132. See id. at 276.

133. However, as Michael Hartmann points out, using judges to try cases in these post-conflict climates can also lead to biased results. See Hartmann, supra note 44, at 4.

134. In England and Wales, for example, the Roskill Committee recommended, in 1986 , that complex fraud cases should not be tried by lay juries. See David J. Feldman, England and Wales, in Criminal Procedure: A Worldwide Study, supra note 62, at 149, $172-73$. 


\section{Control of Investigations in Criminal Cases}

Oversight of investigations in criminal cases can generally be carried out by an Investigating Judge or prosecutor. In contexts where there is an imbalance of power between the prosecution and defense, an Investigating Judge charged with investigating both inculpatory and exculpatory evidence can help to protect the rights of the accused. ${ }^{135}$ This model can also be useful if there are not enough defense attorneys available, which may be the case in post-conflict settings. Supporters of the role of the Investigating Judge also argue that it eliminates the atmosphere of gamesmanship during trial. ${ }^{136}$ On the other hand, critics believe that judges charged with investigating the truth of events may suffer from confirmation bias, which reduces their incentive to investigate alternate theories of the case. ${ }^{137}$ However, the same critique can be made of prosecutors. ${ }^{138}$

\section{E. Role of Police}

Inquisitorial systems can benefit from the service of Judicial Police who work under the supervision of the judiciary during the secret investigation phase. ${ }^{139}$ This is the case in Italy, where certain police officers are under the control of the Investigating Judge during the investigation of cases related to suspected mafia activity. ${ }^{140}$

In adversarial systems, law enforcement officials' interests are in closer alignment with the prosecution, potentially creating an imbalance of arms since the defense does not have access to a similar body of investigators.

\section{F. Role of Defense Lawyers}

In adversarial systems, defense lawyers enjoy more robust opportunities to be heard and to protect the interests of their clients than in inquisitorial systems. ${ }^{141}$ Although this may be beneficial in systems with enough defense lawyers, in systems where their numbers are fewer, the absence of defense counsel during critical stages of the case can be problematic. Thus, care should be taken not to delegate the protection of defense rights to non-existent lawyers. In these situations, a fairer system might delegate

135. This is the case in France, where the Investigating Judge is charged with finding "the objective truth" instead of focusing on "the guilt of a particular suspect." CatHerINE Elliott \& Catherine Vernon, French Legal System 162 (2000).

136. See Pizzl, supra note 103, at 126-28; Roach, supra note 118 , at 390.

137. See Robert P. Mosteller, Failures of the American Adversarial System to Protect the Innocent and Conceptual Advantages in the Inquisitorial Design for Investigative Fairness, 36 N.C. J. Int'L L. \& Com. Reg. 319, 326-27 n.25 (2011).

138. See Roach, supra note 118 , at 401.

139. See WeSt ET AL., supra note 129, at 258.

140. See Elliott \& Vernon, supra note 135 , at 164.

141. In France, an accused's right to meet with defense counsel during detention is much more strictly curtailed than in common law systems. For instance, the initial meeting may not last more than thirty minutes during the first twenty-four hours of detention. If the detention period is extended, the length of sequential meetings with counsel depends on the nature of the charges under investigation. See CODE DE PROCEdure pénale [C. PR. pén.] [Criminal Procedure Code] arts. 63-64 (Fr.). 
those responsibilities to an Investigating Judge. ${ }^{142}$

In systems in which defense lawyers do play important roles, it is important that they are trained and empowered equally alongside other actors in the judicial system. It is not uncommon in post-conflict settings for judges and prosecutors to be trained first with defense lawyers only included later when it becomes clear that cases cannot proceed in their absence. ${ }^{143}$

\section{G. Secrecy of the Investigation Phase}

During traditional, inquisitorial proceedings, investigation of criminal cases is carried out by an Investigating Judge working in a confidential setting away from public view. ${ }^{144}$ Violations of the duty of confidentiality may carry criminal, civil, and disciplinary sanctions. ${ }^{145}$ Advocates of this system credit its protection of the reputation of accused persons who should benefit from the pretrial presumption of innocence and to the ability of judges to fully investigate a case without losing witnesses or risking the destruction of evidence. ${ }^{146}$

However, secrecy in investigation phases has been linked to financial and political corruption since it is easier to buy results when the public and media have no access to judicial processes. ${ }^{147}$ Opportunities for "telephone justice"-when politicians order judges to decide cases in certain ways-may also increase. This is a potential issue in post-conflict settings when domestic courts try serious crimes that arose during the conflict and may involve warring factions. Secret investigations may allow politically inclined judges to dismiss charges filed against persons or groups with whom they sympathize.

\section{H. Judicial Control of Expert Witnesses}

Control over expert witnesses has been the subject of vigorous debate

142. For that reason, in these situations, an individual's direct access to the courts is especially important. See Manisuli Ssenyonjo, Direct Access to the African Court on Human and Peoples' Rights by Individuals and Non Governmental Organisations: An Overview of the Emerging Jurisprudence of the African Court 2008-2012, 2 INT'L HuM. RTs. L. Rev. 17, 20 (2013). Direct access of individuals to the European Court of Human Rights is permitted under Article 34 of the European Convention on Human Rights. European Convention on Human Rights, supra note 95, at art. 34.

143. See, e.g., Amnesty Int'l, Afghanistan: Re-establishing the Rule of Law 30-32 (2003).

144. See Elliott \& Vernon, supra note 135, at 142-43.

145. See, e.g., Code de procédure penale [C. Pr. PEn.] [Criminal Procedure Code] art. 11 (Fr.); Code pénal [C. PEn.] [Penal Code] art. 226 (Fr.); see also Elllott \& Vernon, supra note 135 , at 143 .

146. See Heather Horn, The French Are Unimpressed by American Justice, ATLANTIC Oune 13, 2011), https://www.theatlantic.com/international/archive/2011/06/dsk-trialleaves-french-unimpressed-american-justice/351649 [https://perma.cc/B4ZG-8YKJ].

147. The 1997 Truche Report, issued by the Commission de reflexion sur la Justice in France, recommended reducing the powers of the Investigating Judge and increasing transparency in the criminal justice system. The Commission was convened following allegations that politicians benefitted from secrecy during criminal investigations. See ELLIOTT \& VERNON, supra note 135, at 141-42. 
in recent years. ${ }^{148}$ In adversarial systems, experts may be expected to ally themselves with one side and not testify for the other. ${ }^{149}$ Further, when the accused is indigent, it is unlikely she will have the same access to expert testimony from which the prosecution benefits. ${ }^{150}$

In France, neutrality of experts is ensured by a system that assigns responsibility for obtaining expert witnesses to judges. Each jurisdiction maintains a list of experts organized according to areas of expertise, and the experts are hired by the judge investigating a case. ${ }^{151}$ If the court desires a second opinion, or if either party requests one, the court has authority to engage additional experts. ${ }^{152}$

In Ontario, Canada, the integrity of unbiased expert opinions is maintained by Court Rule 53,153 which requires that expert witnesses provide the name of the party that has hired them and sign an affidavit acknowledging their duty to provide evidence that is fair, objective, and nonpartisan.

\section{Guilty Pleas and Plea Bargains}

The impact of guilty pleas is an issue that has "long divided civil and common law lawyers." 154 In inquisitorial systems, admissions of guilt are taken into consideration along with other evidence in the search for truth; that is, a "full investigation and trial automatically take place, regardless of whether the accused has confessed." 155 Guilty pleas may be prohibited altogether in serious cases because criminal proceedings "in these systems prioritize accurate determination of the truth over the accused's autonomy" in the direction of the case. ${ }^{156}$

148. See generally, e.g., Arthur Daemmrich, The Evidence Does Not Speak for Itself: Expert Witnesses and the Organization of DNA-Typing Companies, 28 Soc. STUD. SCI. 741 (1998).

149. See Mark Hansen, CSI Breakdown, AM. BAR Ass'n J. (Nov. 1, 2010, 9:50 AM), http://www.abajournal.com/magazine/article/csi_breakdown [https://perma.cc/ W2BT-6F38].

150. See Roach, supra note 118 , at 405-06 (citing a study of forty cases in the U.S. "in which DNA analysis revealed eyewitness identifications to be mistaken," and in none of those cases had a defense expert in eyewitness identification been called).

151. For a list of experts available to judges of the Cour de Cassation, see Experts Judiciaires, COUR DE CASSATION (2020), https://www.courdecassation.fr/jurisprudence publications_documentation_2/experts_judiciaires_8700.html [https://perma.cc/ 63MD-3KXQ].

152. See WeSt Et AL., supra note 129, at 297.

153. See Kosta Kalogiros \& Shanique M. Lake, To Comply or Not to Comply? When Experts Fall Outside the Scope of Rule 53.03, MCCARTHY (May 4, 2015), https:// www.mccarthy.ca/en/insights/blogs/canadian-appeals-monitor/comply-or-not-complywhen-experts-fall-outside-scope-rule-5303 [https://perma.cc/DV2T-CU6P]; Form 53: Acknowledgment of Expert's Duty, ONT. CT. FORMS (2007), http://ontariocourtforms.on.ca/static/media/uploads/courtforms/civil/53/rcp-53-e.pdf [https:// perma.cc/3TDY-PCAY].

154. Silvia A. Fernández de Gurmendi, International Criminal Law Procedures: The Process of Negotiations, in The International Criminal Court: The Making of the Rome StatuTe 217, 223 (Roy S. Lee ed., 1999).

155. EtLlotT \& VerNon, supra note 135, at 172.

156. Roach, supra note 118 , at 397-98; see also Montana, supra note 59, at 107. 
In adversarial systems, a confession or guilty plea may be dispositive of the case; and, in some jurisdictions, confessions need not be corroborated. ${ }^{157}$ As a result, there may be cases in which guilty pleas are unrelated to the actual guilt of the accused. ${ }^{158}$

In post-conflict settings, where there are inadequate numbers of defense lawyers, dangers associated with guilty pleas increase when accused persons are unadvised about burdens of proof, their legal rights, and the consequences of a guilty plea. Guilty pleas and plea bargains may therefore be unwise in these contexts. ${ }^{159}$

\section{J. Admissibility of Evidence}

Common law systems tend to include elaborate rules of evidence that prohibit hearsay and other forms of indirect evidence. ${ }^{160}$ Additionally, evidence may be excluded to serve policy preferences, such as discouraging police malfeasance and violations of rights or rules of search and seizure. ${ }^{161}$ This can occur even when the excluded evidence is directly relevant to the truth. ${ }^{162}$

When lay juries are not used, justifications for excluding evidence may decrease. ${ }^{163}$ This is the approach of traditional inquisitorial systems, in which all evidence is admitted and judges decide whether it is probative. ${ }^{164}$ In post-conflict settings in which resources are scarce and common law chain of custody requirements are difficult to meet, the inquisitorial practice of introducing all evidence that may be relative to the truth of the case may be less expensive and cumbersome than common law procedures.

157. See Roach, supra note 118 , at 396.

158. See, e.g., Walter Pavlo, Are Innocent People Pleading Guilty? A New Report Says Yes, FORBES (July 31, 2018, 8:06 PM), https://www.forbes.com/sites/walterpavlo/2018/07/ 31/are-innocent-people-pleading-guilty-a-new-report-says-yes/\#6879b3251937 [https:// perma.cc/5UFS-SP5U]; Jeffrey D. Stein, How to Make an Innocent Client Plead Guilty, WASH. POST (Jan. 12, 2018, 8:00 PM), https://www.washingtonpost.com/opinions/whyinnocent-people-plead-guilty/2018/01/12/e05d262c-b805-1 le 7-a908-a3470754bbb9 story.html?noredirect\&utm_term=.2c0241ca7350 [https://perma.cc/RC62-KJ6F]. Ken Roach argues that "the adversarial system's willingness to accept a guilty plea from a person who may be innocent is an inherent limitation of an adversary system that is based on parties' autonomy in resolving disputes in a manner [that is] in accordance with their interests." Roach, supra note 118, at 392.

159. For various ways that plea bargains have been introduced and adapted in civil code systems, see Máximo Langer, From Legal Transplants to Legal Translations: The Globalization of Plea Bargaining and the Americanization Thesis in Criminal Procedure, 45 HaRv. INT'L L.J. I, 39, 46 (2004).

160. See Mirjan R. Damaška, Evidence Law Adrift 13 (Yale Univ. Press 1997).

161. See Monrad G. Paulsen, The Exclusionary Rule and Misconduct by the Police, $52 \mathrm{~J}$.

CRIM. L. \& CRIMINOLOGY 255, 255 (1961).

162. See DAMAŠKA, supra note 160 , at 13 .

163. Id. at 2 (citing to James Thayer, who claimed that the common law's rules of evidence are primarily "the child of the jury system").

164. See WEST ET AL., supra note 129 , at 146. 


\section{K. Joint Civil and Criminal Trials}

The inquisitorial practice of joining civil cases to criminal proceedings ${ }^{165}$ and allowing judges to determine criminal guilt or innocence while also evaluating potential civil damages-and, if necessary, appropriate criminal punishment-can save costs and ensure legal representation in post-conflict contexts in which resources are limited and lawyers are scarce.

Joining civil and criminal cases can also avoid the risk of inconsistent verdicts, ${ }^{166}$ which can have the consequence of undermining public confidence in judicial systems immediately following conflict, a time when embedding the Rule of Law is especially critical. Burdens of proof, which can differ in civil and criminal cases in common law systems, must be considered if joint trials are implemented.

\section{Judicial Oversight of Civil Cases}

Judicial oversight during civil litigation is much greater in inquisitorial systems than in adversarial systems, in which cases are largely controlled by lawyers. ${ }^{167}$ In France, for example, cases that are not ready on the day of trial are referred to a judge who then assumes an active role preparing the case. This judge, known as the juge de la mise en état, possesses a number of powers necessary to prepare the case for trial when parties have not managed to do so themselves. ${ }^{168}$

In post-conflict settings in which resources are limited, judicial control over civil proceedings can save time and resources and eliminate gamesmanship. However, in situations in which the judiciary is corrupt, judicial control may further decrease public confidence in the Rule of Law.

165. This practice is true in most civil code systems, including in Italy. See Pizzi \& Montagna, supra note 59, at 433 n.7 ("Every criminal offense in Italy also constitutes a civil offense and, as such, there is a right to compensation for the injury to the person injured by the crime."). For example, Italy's Code of Criminal Procedure states that "the civil action to claim compensation or reparation provided for by Codice Penale art. 185 can be brought as part of the criminal trial by the person injured by the crime or by his/ her general successors against the defendant or the person having a civil responsibility." Id. (quoting Codice di procedura penale [C.p.p.] art. 74 (It.)).

166. Allegedly, inconsistent criminal and civil verdicts in the O.J. Simpson case generated global criticism of the U.S. common law system. See B. Drummond Ayres, Jr., Jury Decides Simpson Must Pay $\$ 25$ Million in Punitive Award, N.Y. Times (Feb. 11, 1997), https://www.nytimes.com/1997/02/11/us/jury-decides-simpson-must-pay-25-millionin-punitive-award.html [https://perma.cc/Y7QB-TSD9].

167. See Scott Dodson \& James M. Klebba, Global Civil Procedure Trends in the TwentyFirst Century, 34 B.C. InT'L \& Compar. L. Rev. 1, 9-10 (2011). Common law judges' overall lack of control over court proceedings has been criticized by academics and others. See, e.g., James R. Maxeiner, What America Can Learn from Germany's Justice System, ATLANTIC (June 7, 2012), https://www.theatlantic.com/national/archive/2012/ 06/what-america-can-learn-from-germanys-justice-system/258208 [https://perma.cc/ 92KE-XRRH].

168. ElliotT \& VERNON, supra note 135, at 128. Judges exercise similar control over civil proceedings in Germany. See John H. Langbein, The German Advantage in Civil Procedure, 52 U. CHI. L. Rev. 823, 830-41 (1985). 


\section{Community-Based Institutions}

In rural areas untouched by internationally-sponsored, legal reform efforts, local centers for dispute resolution have been utilized. ${ }^{169}$ These centers, which generally reflect goals of customary law ${ }^{170}$ and are inspired by holistic concepts of justice, reinforce the idea that "the ultimate goal of the legal process is not retribution and punishment for crimes and transgressions of the social order, but rather rehabilitation and community healing." ${ }^{171}$ They have been successfully implemented in Colombia, ${ }^{172}$ where Casas de Justicia, characterized as interinstitutional units that provide information, orientation, referral, and services for the resolution of conflict, meld formal and informal mechanisms that include various ethnic groups' manifestations of justice. ${ }^{173}$

This model is potentially useful in post-conflict settings in which communities have been riven by conflict and are in need of reconciliation, and where national laws and state-sponsored justice systems have lost credibility. ${ }^{174}$

\section{N. Mediation and Arbitration}

In a number of legal systems, mediation is becoming increasingly popular as an alternative to litigation, which can be expensive and protracted. 175 "In some jurisdictions, such as Germany, India, Bermuda, Hong Kong and China, a private, mediated settlement can be converted

169. Alternatives to state-sponsored models can also be viable in non-rural contexts. These models find support among comparatists who argue for the Western models, while also arguing for the expansion of models. See Seidman, supra note 108, at 20, 43 .

170. See Access to Justice Brief, supra note 55, at 16. For example, in rural areas of Timor-Leste,

[most cases] are resolved through the traditional justice system; if a case cannot

be resolved there, it is referred to formal court. Most people prefer to avoid

formal courts since its processes are unfamiliar and are conducted in Portu-

guese or Tetun, which few people speak. Victims in particular tend to prefer

traditional justice mechanisms since resolution of disputes results in concrete

reparations to victims in the form of something useful, such as cattle.

Id. at 13. "However, reparations awarded by traditional leaders do not always comply with requirements of fairness and equality." Id. at $n .18$. Reparations for injury to a female, for example, may be given to her family and not directly to her. Id.

171. Juan Carlos Botero, The Three Faces of Justice: Legal Traditions, Legal Transplants, and Customary Justice in a Multicultural World 225 (2013) (unpublished S.J.D. thesis, Georgetown University Law Center) (on file with the Georgetown University Digitial Repository).

172. See Cecilia Brady, USAid, Building Alliances Series: Democracy 10-11 (2009).

173. See limpal Colombia, Participando . . A Ando a la Sombra de la Resolucion 1325, at 14, 20-21 (2012); see also Botero, supra note 171, at 254 (arguing that in second- and third-world countries, formal and customary systems of dispute resolution "are increasingly misaligned with the changing reality of a globalized yet multicultural world,"and that a third model, based on notions of customary justice, is needed).

174. See Samuels, supra note 113, at 18.

175. In some jurisdictions of the United States, presumptive alternative dispute resolution is on the rise as a strategy to eliminate case backlogs and enhance the quality of justice. See, e.g., Claudia Lanzetta, Be Prepared: 'Presumptive ADR' Is Coming, N.Y. L.J. (Aug. 2, 2019), https://www.law.com/newyorklawjournal/2019/08/02/be-preparedpresumptive-adr-is-coming [https://perma.cc/DU6B-JWCE]. 
into an arbitral award, thereby enjoying the same enforceability as a court judgment."176 Principles of private arbitration that are enforceable in national courts are consistent with practices of religious tribunals used in some communities. ${ }^{177}$

\section{O. Mobile Courts}

Although technically not an aspect of a specific legal system, mobile courts have proven useful in rural areas where communities are recovering from conflict and are disillusioned with the state court system. In TimorLeste, for example, victims, witnesses, and suspects were brought from different regions of the country to participate in hearings held in police stations and government offices. ${ }^{178}$ In Liberia, judges, prosecutors, and defense advocates were brought to detention facilities to try criminal cases, thereby avoiding logistical difficulties in transporting detainees to other facilities. ${ }^{179}$

Mobile courts have proven useful in these circumstances to demonstrate to communities that courts are functioning and to address transportation and infrastructure deficiencies while educating the public on judicial procedures.

\section{Skepticism Towards Hybridity}

The tinderbox and toolkit dichotomy suggested in this Article-which proposes that legal systems be disaggregated, and their component parts analyzed for possible contributions to creating and resolving conflictpresents several potential risks. One of these risks is that the selected advisers will fail to implement the strategy because they lack adequate training in other legal systems. ${ }^{180}$ Among academics, resistance might

176. Steven Austermiller, Cambodian Alternative Dispute Resolution, in INTRODUCTION to Cambodian Law 181, 190 (Hor Peng et al. eds., 2012) (citations omitted); see also Arbitration and Conciliation Ordinance Act, No. 26 of 1996, INDIA CODE (1996), arts. 73-74; Zivilprozessordnung [ZPO] [Code of Civil Procedure], \& 1053 (Ger.); Zhōnghuá Rénmín Gỏnghéguó Zhòngcái Fa (中華人民共和國仲裁法) [Arbitration Law of the People's Republic of China] (promulgated by the Standing Comm. Nat'l People's Cong., Aug. 31, 1994, effective Sept. 1, 1995) 1995 Standing Comm. Nat'l People's Cong. GAZ. 717, art. 51 (China); Arbitration Ordinance, (1997) Cap. 341, 5, \& 2C (H.K.).

177. For example, judgments rendered by Beth Din courts are enforceable in secular courts pursuant to binding arbitration agreements signed by parties. In this way, parties are able to settle disputes according to religious law. Din Torah (Arbitration) Services, BETH Din AM., https://bethdin.org/dintorah [https://perma.cc/3H98-K7FF] (last visited Aug. 13, 2019).

178. See Access to Justice Brief, supra note 55, at 10.

179. See Magistrate Sitting Program in Liberia, JUDICIARY, http://judiciary.gov.lr/magistrate-sitting-program [https://perma.cc/3Y6R-KMFP] (last visited Aug. 13, 2019).

180. Menski refers to conversations with well-educated, practicing lawyers, who confirmed that their greatest knowledge gap is a lack of "insight into legal systems other than the ones in which they are" expected to practice. MENSKI, supra note 57 , at 45 . The lack of training in legal systems other than their own among so-called legal experts posed a challenge during negotiations of the Rome Statute. See Fernandez de Gurmendi, supra note 154, at 220. 
arise due to historical biases against hybrid legal systems, which result when aspects of different legal system are intermixed. ${ }^{181}$ For those mindful of post-colonial legacies, hybridity is often negatively associated with issues of injustice and power. ${ }^{182}$

However, much of the criticism of hybrid systems is misplaced and based on conflations in terminology. ${ }^{183}$ Roger Mac Ginty and Oliver Richmond review the recent interest in hybridity during peacebuilding processes in the context of hybrid political orders. ${ }^{184}$ While their critique relates to a different context, their view on hybridity bears a close look in the context of post-conflict legal systems:

In terms of conceptual discussion, it is worth noting how hybridity frees us from the rigidities of standard categories and binaries often deployed to explain peacebuilding and statebuilding mainly as exercises of top-down power and leadership. It allows us to build holistic accounts of conflicts and escape orthodox conflict analysis templates that seem unaware of inconsistency, margins, dissent, gender and all things that make the human experience variegated and contingent. It further allows us to see more clearly the multiple sources of power and agency that constrain and enable. Fundamentally, the concept of hybridity, if used as a post-colonial, post-territorial and post-biological construct, liberates us from the dominant policy script

181. In one case, the hybrid system introduced by UNTAET in Timor-Leste was unartfully and perhaps unfairly termed a "mishmash." Suzannah Linton, Rising from the Ashes: The Creation of a Viable Criminal Justice System in East Timor, 25 MELB. U.L. Rev. $122,174(2001)$. A radio commentator even stated, in the context of Timor-Leste's transition to independence and the necessity for a new legal order, "[p]ossible ingredients for the recipe come from Portuguese law, Indonesian law, local customary law and UNTAET's own regulations which incorporate human rights obligations. None of the ingredients alone offers the perfect recipe-so we examine the legal 'stir-fry' which is being painstakingly concocted." Jennifer Feller, Take Four Legal Systems and Stir!, LAW REP. (July 11, 2000), https://www.abc.net.au/radionational/programs/lawreport/takefour-legal-systems-and-stir/3469360\#transcript [https://perma.cc/6FGS-Z4ZT].

182. Jenny H. Peterson, A Conceptual Unpacking of Hybridity: Accounting for Notions of Power, Politics and Progress in Analyses of Aid-Driven Interfaces, $7 \mathrm{~J}$. Peacebuilding \& Dev. 9,14 (2012) ("A second and perhaps more problematic critique of hybridity relates to the absence or downplaying of issues of injustice and power.").

183. Julian Graef, for example, analyzes hybridity in peacebuilding practices in the context of agency and power redistributions by looking to post-liberal peace and conflict studies. See Julian Graef, Practicing Post-Liberal Peacebuilding: Legal Empowerment AND EMERGENT Hybridity IN LIBERIA 1-5 (2015). Gearoid Millar states that hybridity has become a popular term of art in "recent peacebuilding scholarship to describe ... hybrid peacekeeping missions, hybrid criminal tribunals, hybrid governance, and the hybrid peace." Gearoid Millar, Disaggregating Hybridity: Why Hybrid Institutions Do Not Produce Predictable Experiences of Peace, 51 J. PeAce RsCH. 501, 501 (2014). However, he argues that the concept of hybridity has been "under-theorized and variably applied," and that actors who believe they "can plan and administer hybridity to foster predictable social experiences in complex post-conflict states" are mistaken. Id. Interestingly, Millar also states that "the desire to sustain the relevance of academic theory and international practice to contemporary conflict .... drive[s] theorists of hybridity towards prescriptive, as opposed to purely descripti[ve], approaches." Id. at 504 .

184. See Roger Mac Ginty \& Oliver Richmond, The Fallacy of Constructing Hybrid Political Orders: A Reappraisal of the Hybrid Turn in Peacebuilding, 23 INT'L PEACEKEEPING 219,219 (2016) (criticizing "the ability of international actors to manufacture with precision hybrid political orders, and argu[ing] that the shallow instrumentalization of hybridity is based on a misunderstanding of the concept."). 
of goodies and baddies, states and non-states and West and non-West. The world we inhabit is much more complex that [sic] the binary-world inscribed in many peacebuilding and statebuilding policies and so it demands agile conceptual and analytical vehicles. Hybrid contexts are not necessarily part of a transition from one condition (possibly traditionalism) to another (possibly modernity). Instead, they deserve to be viewed in their own right. However, they also raise vast structural issues of historical and distributive inequality, and the dismantling and replacing of long-standing power structures-social, cultural, political and economic hierarchieswhich need to be responded to in long-term processes if peace is to be positive and hybrid simultaneously. ${ }^{185}$

\section{Hybridity in Legal Systems}

In the context of law and legal systems, the concept of hybridity should be less controversial than in other disciplines. Some scholars believe that no legal system has been truly pure since the Middle Ages. ${ }^{186}$ More conservatively, data from the University of Ottawa indicates that today the majority of the world's people $-68 \%$ of the global populationlive in mixed legal systems. ${ }^{187}$ A review of literature in the fields of Comparative Criminal Procedure and Comparative Civil Procedure reveals the wide variety of system models in place around the world. ${ }^{188}$

Even within Western systems, comparatists tend to agree that distinctions between civil code and common law systems may no longer be valid. ${ }^{189}$ Guy I. Seidman outlines three ways in which the convergence phenomenon can be explained. ${ }^{190}$ First, in hindsight, it may be doubted that distinct models of legal systems ever existed. ${ }^{191}$ Second, increasing study of other legal systems led to explicit borrowing and adoption. ${ }^{192}$ Third, "with the rise of international and supranational [legal] regimes,

\footnotetext{
185. Id. at 229.
}

186. Reinhard Zimmermann, Roman Law, Contemporary Law, European law: The Civilian Tradition Today 159 (Oxford Univ. Press 2001). A mixed system is distinguishable from a pluralist system in which elements of two or more legal systems coexist but do not necessarily intermingle. Pluralist systems have "often taken place when a people has lost its political sovereignty, yet has somehow preserved the right to continue livng in accordance to its personal or private laws." Vernon Valentine Palmer, Mixed Legal Systems, in The Cambridge Companion to Comparative Law 368, 377 (Mauro Bussani \& Ugo Mattei eds., 2012).

187. Graph of Distribution of the World Population (\%) Per Legal Systems, UnIv. OTTAWA, http://www.juriglobe.ca/eng/syst-demo/graph.php [https://perma.cc/TM4DZ5A5] (last visited Aug. 15, 2019). This data does not appear to disaggregate hybrid and pluralist systems.

188. See John W. Head, Great Legal Traditions: Civil law, Common law, and Chinese Law in Historical and Operational Perspective 12 (2011). See generally Criminal Procedure: A Worldwide Study (Craig M. Bradley ed., 2d ed. 2007); Thaman, supra note 60 ; Ebbe, supra note 130.

189. See Seidman, supra note 108, at 20. Seidman states that the "two arch-models of common and civil law are drawing closer" over time, evidencing system convergence. Id.; see also Montana, supra note 59, at 108.

190. See Seidman, supra note 108 , at 20.

191. See id.

192. See id. 
efforts are being made to minimize the differences between legal systems in order to harmonize national laws."193

\section{Hybridity in International and Domestic Courts and the Model Codes Project}

Hybrid systems are already present in international courts, including in the International Criminal Tribunal for the Former Yugoslavia (the Tribunal) and the International Criminal Court.

The Rules of Procedure and Evidence (the Rules) at the Tribunal, negotiated over the course of two years by a mix of civil and common law lawyers, 194 were "the first coherent body of principles governing the prosecution" of international law. ${ }^{195}$ The Rules contain elements from both adversarial and inquisitorial systems and reflect tensions between the need to expedite trials and to protect the rights of the accused. ${ }^{196}$ Consistent with civil code practices, which delegate oversight of cases to judges, responsibility for ensuring that trials are both fair and expeditious is assigned to Trial Chambers. ${ }^{197}$ Elements of each system include: the right to closed hearings in the interest of victims and witnesses; ${ }^{198}$ the duty to present "witness statements . . . before trial, not as evidence, but rather to ... familiarize [judges] with the case"; 199 the duty of the defense to "set[ ] out in general terms the defen[s]e to the indictment, ... [and] any motions, by certain specified dates"; 200 and the duty of the defense to provide the prosecution with a list of intended witnesses. ${ }^{201}$ Rule 89 governs admissibility of evidence and, consistent with inquisitorial practice, provides that a Chamber "may admit any relevant evidence which it deems to have probative value" 202 and may receive witness testimony "orally or, where the interests of justice allow, in written form." ${ }^{203}$ Although judges may refer to

193. Id. (alteration in original).

194. See 1 Virginia Morris \& Michael P. Scharf, An Insider's Guide to the International Criminal Tribunal for the Former Yugoslavia: A Documentary History and ANALYSIS 180 (1995).

195. Gideon Boas, Creating Laws of Evidence for International Criminal Law: The ICTY and the Principle of Flexibility, 12 CRIM. L.F. 41, 41 (2001).

196. See id. at 41-42; see also DAMASKKA, supra note 160, at 1-2 n.1.

197. See Statute of the International Criminal Tribunal for the Former Yugoslavia art. 20, 91 , May 23, 1995, 32 I.L.M. 1192 ("The Trial Chambers shall ensure that a trial is fair and expeditious and that proceedings are conducted in accordance with the rules of procedure and evidence, with full respect for the rights of the accused and due regard for the protection of victims and witnesses.").

198. See Boas, supra note 195, at 44.

199. Id. at 45 .

200. Id. at 46 (citations omitted). This concept is now embodied by Rule 65 ter. See Rules of Procedure and Evidence, International Criminal Tribunal for the Former Yugoslavia, Rule 65ter, July 18, 2015, IT/32/Rev.50 [hereinafter Rules of Procedure and Evidence].

201. See Boas, supra note 195, at 47.

202. Rules of Procedure and Evidence, supra note 200, at Rule 89(C).

203. Id. at Rule $89(\mathrm{~F})$. 
national rules of evidence, they are not bound by them. ${ }^{204}$ Unsurprisingly, legal scholars did not unanimously support the creation of these hybrid rules, with some charging that the Tribunal was jurisdictionally unsound and "a rogue court with rigged rules." 205

The Rome Statute, which serves as the legal foundation of the International Criminal Court, was negotiated between 1995 and 1998 and includes elements of both adversarial and inquisitorial systems. ${ }^{206}$ Issues debated during the drafting process included the impact of guilty pleas, rights of suspects, admissibility of evidence, and mechanisms to protect victims and witnesses. ${ }^{207}$

In response to paragraph eighty-one of the Brahimi Report, ${ }^{208}$ the United States' Institute of Peace, the Irish Centre for Human Rights, the Office of the U.N. High Commissioner for Human Rights, and the U.N. Office on Drugs and Crime developed the Model Codes to fill gaps in peace operations where previous legal systems have lost credibility. The Model Codes drew elements from all the major legal systems of the world and were strongly influenced by Comparative Law discourses in international tribunals as well as concrete experiences of advisers working in post-conflict environments. ${ }^{209}$ Hybrid in nature, and reflecting the recognition that conflict introduces distinct exigencies during legal reform, the Model Code of Criminal Procedure includes rules of evidence that permit hear-

204. See Boas, supra note 195, at 49 (quoting Trial Chamber III in Prosecutor v. Kordiæ and Ėerkez, Case No. IT-95-14/2-T, Decision on the Prosecution Application to Admit the Tuliæa Report and Dossier into Evidence, ' 12 (Int'l Crim. Trib. for the Former Yugoslavia July 29, 1999))

205. Boas, supra note 195, at 48 (citations omitted); see also Vera Gowlland-Debbas, Security Council Enforcement Action and Issues of State Responsibility, 43 INT'L \& COMPAR. L.Q. 55, 56 (1994); Gabriell H. Oosthuizen, Playing the Devil's Advocate: The United Nations Security Council Is Unbound by Law, 12 LEIDEN J. INT'L L. 549, 549 (1999).

206. See M. Cherif Bassiouni, Negotiating the Treaty of Rome on the Establishment of an International Criminal Court, 32 CORNELl INT'L L.J. 443, 443-44, 464 (1999). Bassiouni, who served as Chair of the Drafting Committee, provides insight into the pitfalls of negotiating the contents of an international treaty with experts from different legal systems. Because some of the provisions of the Rome Statute were eventually resolved politically and diplomatically, the risk of creating a legal framework without internal coherence existed. Challenges in sensitizing members of the Drafting Group to aspects of legal systems different from their own was addressed, in part, by adjusting normal U.N. seating arrangements so that members would focus on the text of the draft. This strategy also diminished the psychological implications of adhering only to nationalistic positions. Id. at 452; see also Elisabetta Grande, Comparative Criminal Justice, in THE Cambridge Companion to Comparative Law, supra note 186, at 191, 193. Grande argues that with the advent of international criminal tribunals, including the International Criminal Court, comparative criminal procedure went from a theoretical discipline to a practical one, which required integrative comparative searches to discover the applicable law. Id.

207. See Fernández de Gurmendi, supra note 154, at 223.

208. Brahimi Report, supra note 8,981 .

209. See 2 Model Code of Criminal. Procedure: Model Codes for Post-Conflict CRIMINAL JustiCe 345 (Vivienne O'Connor \& Colette Rausch eds., 2008) [hereinafter Model Code of Criminal Procedure]; see also U.S. Inst. Peace, https://www.usip.org/ ?site_keywords=model\%20Codes [https://perma.cc/N3LQ-7PB5] (last visited Aug. 15, 2019) (search for "model codes"). 
say $^{210}$ and specify mandatory and discretionary exclusion of evidence. ${ }^{211}$ Responsibility for investigating criminal cases is delegated to prosecutors, as opposed to investigating judges, ${ }^{212}$ and prosecutors are required to investigate exonerating as well as incriminating evidence. ${ }^{213}$ Victims may participate in criminal proceedings if judges so authorize, as opposed to their automatic right to participate in civil code systems. ${ }^{214}$ Common law aspects of the Model Code of Criminal Procedure include the adversarial nature of the proceedings, ${ }^{215}$ the standard of proof, 216 and the principle requiring live testimony at trial. ${ }^{217}$ Civil code aspects include the power of judges to compel the production of evidence during trial. ${ }^{218}$

System convergence-or, in other words, system hybridity-is also increasing within a number of domestic legal systems. Although traditionally, judicial opinions in civil code systems did not carry precedential weight, ${ }^{219}$ jurisprudence has become increasingly available in civil code systems in recent years, ${ }^{220}$ indicating its increasing precedential value. ${ }^{221}$ For example, French judges have spoken openly of their reliance on judicial precedent, ${ }^{222}$ and in Vietnam-a historically civil code system-the use of precedent "was officially recognized by [the] Supreme People's Court in 2016."223 At the same time, common law systems have become increas-

210. See Model Code of Criminal Procedure, supra note 209, at 345-46.

211. See id. at 345-58.

212. See id. at $91-92$.

213. See id. at $93-94$.

214. See id. at 135. The primary concern when drafters were debating this issue was the general absence of lawyers in post-conflict settings, which often results in insufficient lawyers for accused persons. Adding the right of victims to lawyers would only further burden legal systems struggling to recover from conflict. E-mail from Vivienne O'Connor, Rule of Law Project Officer, Irish Centre for Human Rights (Oct. 18, 2011, 11:08 EST) (on file with author).

215. See Model Code of Criminal Procedure, supra note 209, at 338.

216. Id. at 336.

217. See id. at 345 .

218. See id. at 362 .

219. See Code civil [C. crv.] [Crvll Code] art. 5 (Fr.); see also Elliott \& Vernon, supra note 135, at 50; Olivier Moréteau, Codes as Straight-Jackets, Safeguards, and Alibis: The Experience of the French Civil Code, 20 N.C. J. INT'L L. \& COM. REG. 273, 281 (1995).

220. See, e.g., Common Portal of Case Law, Network Presidents Supreme Jud. Cts. Eur. UNION, http://www.reseau-presidents.eu/rpcsjue/index.php [https://perma.cc/ DQR8-LRXK] (last visited Aug. 15, 2019); Legal Databases, EUR. UnIV. INST., https:// www.eui.eu/Research/Library/ResearchGuides/Law/Legal-Databases [https://perma. cc/TJ9Z-LVCZ] (last visited Aug. 15, 2019); Case-Law, EUR-Lex, http://eur-lex.europa. eu/collection/eu-law/eu-case-law.html [https://perma.cc/8JP6-X]4N] (last visited Aug. 15, 2019); Recherche Simple Dans La Jurisprudence Judiciaire, LEGIFRANCE, https:// www.legifrance.gouv.fr/rechJuriJudi.do?reprise=true\&page=1 [https://perma.cc/2VSPLBXP] (last visited Aug. 15, 2019).

221. Not all comparatists are enthusiastic about this trend. Patrick Glenn characterizes common law judges, who traditionally have the power to make law, as "law-seekers, and not law-appliers. They are self-disciplining loose cannons, dangerous for systems." GLENN, supra note 109 , at 257.

222. See Alain Lacabarats, The State of Case Law in France, 51 Loy. L. Rev. 79, 83 (2005).

223. USAID Helps Vietnam Strengthen the Rule of Law Through Advancing Use of Precedent, U.S. AGENCY INT'L Dev. (Aug. 4, 2017), https://www.usaid.gov/vietnam/program- 
ingly codified: as of August 2019, all fifty states in the United States had enacted Criminal Codes; 224 forty-nine states had enacted Codes of Criminal Procedure; 225 and thirty-seven had enacted Codes of Civil Procedure. ${ }^{226}$ As Patrick Glenn states, "[l]egislation in the U.S.[] has . . . assumed civilian proportions and often receives civilian treatment. ${ }^{227}$

System convergence is also prevalent in countries with sizeable indigenous populations, where lawyers and academics are finding new ways to engage with indigenous laws. Issues that arise in these contexts mirror those that appear in other converging systems: legitimacy, harmonization, and potential conflicts of law. ${ }^{228}$ Innovative applications of indigenous law in state courts, including during sentencing proceedings, can be found in Canada, ${ }^{229}$ Alaska, ${ }^{230}$ and Minnesota, ${ }^{231}$ among other jurisdictions. ${ }^{232}$

updates/aug-2017-usaid-helps-vietnam-strengthen-rule-law-through-advancing-use-precedent [https://perma.cc/UP5H-ZKJB].

224. See Statutes-Federal and State Criminal Law Statutes: R-Z, PACE L. SCH. LiBr., https://libraryguides.law.pace.edu/c.php?g=319371\&p=2133330 [https://perma.cc/ 29CL-D922] (last visited Aug. 15, 2019).

225. The exception is Kentucky, where criminal procedure provisions form rules instead of a code. Nevertheless, the rules are codified. See Criminal Rules of Procedure-Annotated Index-KY, LAW READER, https://lawreader.com/?p=12766 [https:// perma.cc/VB3M-2RDF] (last visited Aug. 15, 2019). Codification of civil (as opposed to criminal) law in the United States has always faced greater resistance than codification of criminal law. The Field Civil Code, completed in 1862, was rejected entirely in New York, where it had been drafted, although it was later adopted in California, North Dakota, South Dakota, and Montana. Wienczyslaw J. Wagner, Codification of Law in Europe and the Codification Movement in the Middle of the Nineteenth Century in the United States, 2 Sr. Louis U.L.J. 335, 353-54 (1952).

226. Civil Procedure-State Laws, LEGAL INFO. INST., https://www.law.cornell.edu/ wex/table_civil_procedure [https://perma.cc/E22G-L9GN] (last visited Aug. 15, 2019). Civil codes are far less common; fewer than seven states had codified civil law as of August 2019. Id.

227. GLENN, supra note 109 , at 264 . At least one scholar states that the common law is inherently codified even without formal codes since "every statement of law, every case, and every treatise is already codifying in some way in that it seeks to formulate a rule that will apply to more than the instant case." Lindsay Farmer, Codification, in THE Oxford Handbook of Criminal Law 379, 381 (Markus D. Dubber \& Tatjana Hörnle eds., 2014). Farmer argues that the question is not whether the law should be codified, but whether it should be codified in a particular way. See id. at 382 .

228. Val Napoleon \& Hadley Friedland, Indigenous Legal Traditions: Roots to Renaissance, in The OXford HandBook OF Criminal. Law, supra note 227, at 225, 240.

229. Id. at 236 ("These innovative court processes operate within the mainstream justice system, conform to Canadian criminal procedure, and apply the Criminal Code.").

230. See generally Alaska State Court Acts to Advance Tribal Circle Sentencing, InDIGEnous Peacemaking Initiative (Feb. 7, 2018), https://peacemaking.narf.org/2018/02/ article-alaska-state-court-acts-to-advance-tribal-circle-sentencing [https://perma.cc/ P4EB-Q5NT].

231. See generally Restorative Justice Factsheet, Minn. State L. Libr., http://mn.gov/ law-library-stat/archive/urlarchive/c9992021.pdf [https://perma.cc/R7ST-W3B4].

232. For an informative description of judicial process in Bantu legal proceedings, see generally A.L. Epstein, Juridical Techniques and the Judicial Process: A Study in African Customary Law, in Rhodes-Livingstone PaPers (Rhodes-Livingstone Papers No. 23, 1954). 


\section{The Need for Systemic Thinking 233}

The toolkit approach should be used with care; attention must be paid to the holistic system being created. Transplanting elements of one legal system into another in which safeguards and checks and balances are lacking risks creating new problems and perpetuating old weaknesses. ${ }^{234}$ Worse, careless transplants may undermine underlying systems' goals and values, which vary among legal traditions. ${ }^{235}$ Unless legal systems function as whole, systematic entities with internal coherence, issues-and conflict-are likely to return. ${ }^{236}$ Transplanting procedural rules without an understanding of the interconnective web of relationships among them may be even more delicate than transplanting substantive law. ${ }^{237}$

Tradeoffs in process choices are not always simple; providing greater protections for criminal defendants, for example, will almost certainly result in delays in investigation, prosecution, and adjudication, potentially in violation of time limits set by domestic or international law. ${ }^{238}$ Without regard for the entirety of the legal system being constructed, problem-solving goals will not be achieved, and weaknesses associated with each system may simply be replicated. One Investigating Judge who opposed Sarkozy's proposed introduction of adversarial aspects into the French inquisitorial system stated,

I do [not] deny improvements can be made, but the objective should be to prevent errors rather than suppress an important function in France's justice system to give it a little more of an Anglo-Saxon look. ... Doing that will fix

233. The benefit of systemic thinking is not universally accepted by comparatists. Patrick Glenn associates systemic thinking with Western thought, stating that it is part of the problem with Comparative Law and calling it "The Great White Lie of Western Legal Theory." GLENN, supra note 109 , at xxvii.

234. As Jorge L. Esquirol states, "[i]t stands to reason . . . that the introduction of development reform in Latin America would proceed differently than in an Eastern Europe transitioning from command economies or in an Africa still consolidating relatively new independent states." Esquirol, supra note 71 , at 90 . This problem may be especially acute when transplanting elements of common law systems, since safeguards in that system are not always the product of deliberate design, but instead created in an ad hoc manner for sui generis reasons. See Picker, supra note 110 , at 55.

235. However, Jonathan Miller notes that "there has been significant debate" since the time of Montesquieu about whether law is "sufficiently autonomous to allow the transplant of norms from one society to another," or whether "law must be rooted in a [specific] social, economic, and political context." Miller, supra note 70 , at 844 n. 24 .

236. In Haiti, plans for strengthening the entirety of justice sector actors-police, prosecutors, magistrates, and courts-were conducted separately instead of integrating all actors into one comprehensive development plan. The result was that all strategies failed. See Stromsem \& Trincellito, supra note 68 , at 4.

237. See 48 Guy I. Seidman, Comparative Civil Procedure, in The Dynamism of Civil Procedure-Global Trends and DeVelopments, supra note 108, at 3, 6; see also Scott Dodson, Comparative Convergences in Pleading Standards, 158 U. PA. L. ReV. 441, 445 (2010); Dodson, supra note 125, at 137 n.21; Richard L. Marcus, Review Essay, Putting American Procedural Exceptionalism into a Globalized Context, 53 Aм. J. COMPAR. L. 709, 710 (2005) ("E]ven if procedure is not entwined with culture, it may consist of pieces that are so interdependent that borrowing some substitutes from others would risk upsetting the whole.").

238. See Bassiouni, supra note 206, at 465. 
nothing and leave us with the inconveniences of both systems. ${ }^{239}$

Political and fiscal realities in post-conflict settings must also be taken into consideration. Legal system reforms that reallocate or reduce opportunities for corruption may be resisted by those holding power. ${ }^{240}$ Reforms that cannot be implemented for financial or other reasons will not only waste resources, but also risk undermining public confidence in justice systems at vulnerable junctures. ${ }^{241}$ As Stromseth states, "developing a reasonably functioning justice system requires astute attention to how the various components relate to one another and to the larger political system and culture in which they are embedded." 242

Finally, when changes to laws and systems are negotiated from political-as opposed to technical or substantive-standpoints, an additional set of issues can arise. As $\mathrm{M}$. Cherif Bassiouni narrates in his history of negotiations regarding the Rome Statute, delegates to the drafting process came from a variety of legal systems and traditions. Their assigned task was to achieve political agreement - "even at the cost of creating a consistent and

239. Crumley, supra note 60 (quoting investigative judge Marc Trévidic). In the context of legal reforms in Latin America, Jorge Esquirol states:

[R]eforms advance a specific legal and institutional reconfiguration of criminal law and its enforcement. Yet, other than making broad statements about democracy and human rights, reformers mostly do not consider the multiple policy implications that these shifts entail. More prosecutions and speedier trials mean a different balance between civil liberties and powers of enforcement. Switching control of the criminal investigation from judges of instruction to prosecutors means a re-assignment of resources having a range of possible effects. It may insulate the trial phase from the criminal investigation, but it may not eliminate any of the problems involving discretion, simply shifting it to a different office or to officials with different titles. It may also negatively affect defendants' rights in the investigation phase, previously under the direction of an active judge. In short, pursuing criminal procedure reform as if merely replacing the inquisition with democracy, or some other such generalization, obscures the alternate policies sought to be put in place.

Esquirol, supra note 71 , at 109.

240. See Langer, supra note 159, at 3. Jane Stromseth cautions against inadvertent shifts in power dynamics when engaging in system reform and states that if advisers "focus solely on building up state institutions, ... [they may] inadvertently give selfinterested power-holders more effective institutional tools to advance their own agendas . ..." STROMSETH ET AL., supra note 16, at 179.

241. For example, the introduction of adversarial features into the Russian criminal justice system in 2002, as an attempt to ensure equality of arms, failed to consider low numbers of criminal defense lawyers in the country and the inability of most Russians to afford one. See Newcombe, supra note 62, at 398. In post-conflict Cambodia, introduction of the new Civil Code posed enormous implementation challenges because it was far more complex than any previous law had been. The introduction of intellectual property and administrative laws, the result of Western legal advice, were almost entirely unfamiliar to Cambodian jurists and therefore nearly impossible to implement. See Menzel, supra note 32 , at 486 .

[E]ven where provisions are formally copied "one to one" they will often function somewhat differently in another legal system, particularly when the overall legal culture is significantly different in the two states. Some comparative law scholars even think that legal transplants are generally impossible due to this Id. transformation, although that opinion might be an academic exaggeration.

242. Stromseth Et AL., supra note 16 , at 179. 
coherent legal method[ology]."243 At times, their solution was to build ambiguities into the Rome Statute and leave them for the courts to deal with at a later date. ${ }^{244}$ This solution, of course, can be problematic in postconflict settings when judiciaries are immature or understaffed and judges are not yet fully trained.

\section{Conclusion}

The shadow of conflict is long. Unaddressed legacies of violence and oppression can fester for generations within justice systems, making them instruments of grievous harm. In the United States, for example, stains from the oppression of African Americans subjected to servitude prior to the Civil War still linger in its court system. As recently as June 2019, the Supreme Court referred to post-Civil War constitutional and legislative reforms, including the Equal Protection Clause of the Fourteenth Amendment, the 1873 Slaughter-House Cases, and the Civil Rights Act of 1875, as the fulcrum for invalidating ongoing discriminatory practices in criminal proceedings, decrying covert attempts by prosecutors to avoid their application. ${ }^{245}$

Long-term impacts of colonization can be just as devastating. 246 Colonial movements, for example, drove well-established, indigenous African legal traditions into near oblivion, causing fierce struggles to reassert the legitimacy of customary law. ${ }^{247}$ As Menski states,

[i]t is amazing how self-contradictory the legal arguments over colonial rule in Africa are. While many authors realise that pre-colonial Africa had its own, well-established legal systems and was not a tabula rasa, those same authors often apply culture-blind legocentric assumptions, behaving as though modern Western laws simply brought salvation to Africa. ${ }^{248}$

Whether initiated locally or with the assistance of international advisers, legal system reform will inevitably continue to be an important part of

243. Bassiouni, supra note 206 , at 460 .

244. See id. at $462,464$.

245. See Flowers v. Mississippi, 139 S.Ct. 2228, 2238-39 (2019). Some argue that the political transformation that took place following the Civil War and during the Civil Rights era was incomplete and that a transitional justice process, similar to that undertaken in South Africa and other countries following conflict, would help in finally establishing a racially just society in the United States. See, e.g., Andrew Valls, Racial Justice as Transitional Justice, 36 PoLiTy 53, 53 (2003).

246. See Napoleon \& Friedland, supra note 228, at 247.

247. See MENSKI, supra note 57, at 21-22; see also T.W. Bennett, Comparative Law and African Customary Law, in The OXford HandBook OF Comparative LAw, supra note 103, at $652,654-55$.

The European powers had a curious relationship with their African countries, one that has been described as an unhappy blend of tyranny and paternalism. Because all major decisions were made by absentee sovereigns, far removed from the sites of implementation, relations between rulers and subjects were, at best, a "working misunderstanding." Even today, this phrase would be an apt Id. description of customary law.

248. MENSKI, supra note 57, at 444. 
post-conflict reconstruction processes. In these contexts, although reform of constitutional and substantive law will remain a priority, it is fair and equal procedural law - "the bedrock on which much of social structure is based"-that is at the heart of achieving justice. ${ }^{249}$

The proposed problem-solving model utilizing a Comparative Law methodology seeks to assist in identifying root causes of conflict and avoiding perpetuating or replicating pre-conflict and colonial practices. It is also consistent with modern trends in pluralist systems around the world, including in the European Union. ${ }^{250}$ As Picker states, Comparative Law-led change "may [now] be unstoppable." ${ }^{251}$ It may almost be the case that "Comparative Law-led change may become so normalized as to not even be noticed-if that has not already happened." 252

249. Seidman, supra note 237 , at 5 .

250. See Lenaerts \& Gutman, supra note 103 , at 844.

251. Picker, supra note 110 , at 58 .

252. Id. Indeed, discussions are taking place in the field of Comparative Law on topics not even articulated a decade ago. In the 2010 case Taxquet $v$. Belgium, for example, the European Court of Human Rights addressed the use of reasoned jury verdicts in criminal cases. See generally Taxquet v. Belgium, Eur. Ct. H.R. (2010). Remarkably, none of the seventeen judges sitting as members of the Grand Chamber were from a common law system - the strongest proponent for the use of juries. In Taxquet, the validity of jury trials was simply taken for granted. 